\title{
Investigating Early Dramaturgy and Theatre Directing in the Shabih'khani of the Qajar Era
}

Reza Kouchek-zadeh and Milad Azarm

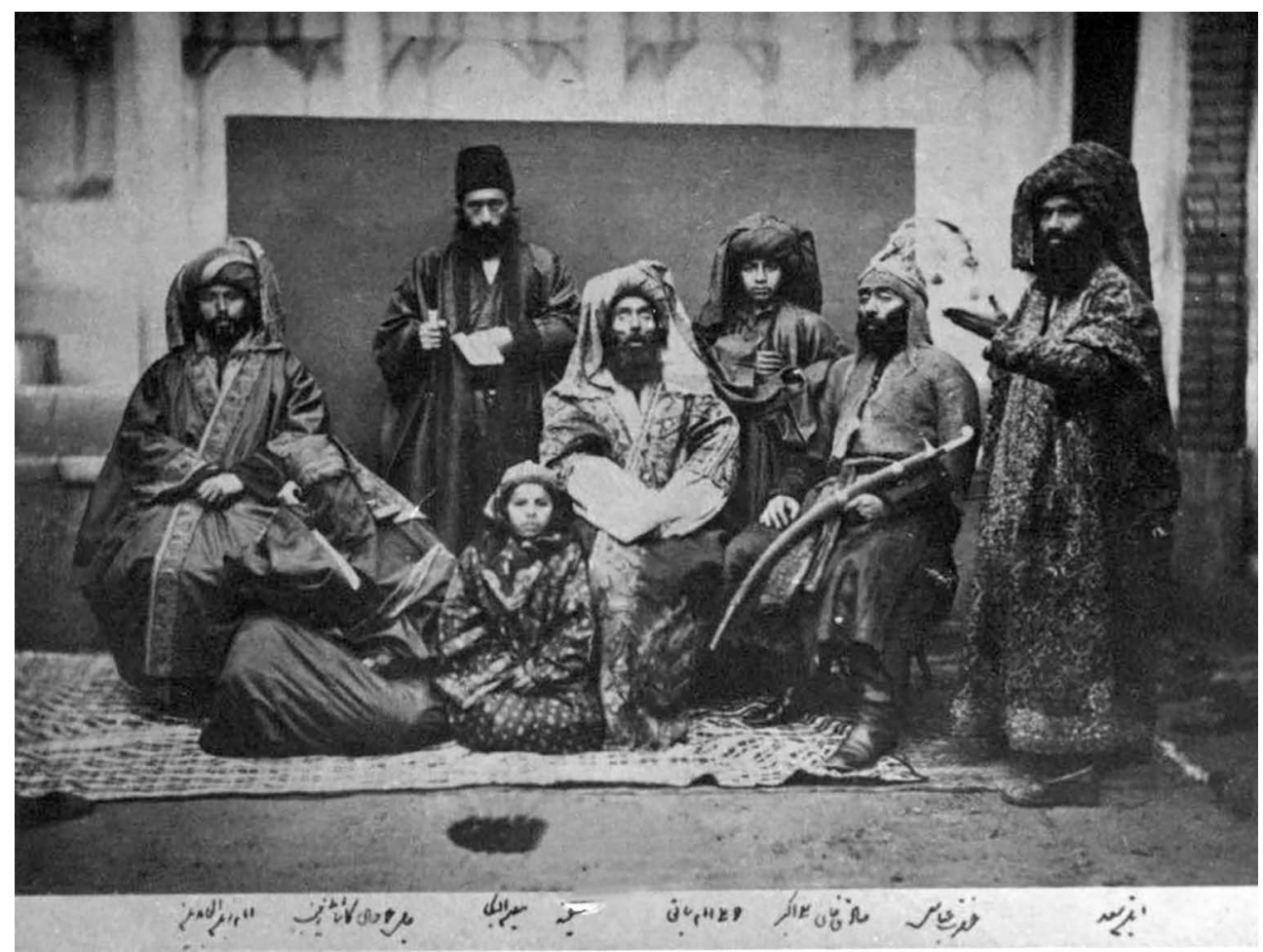

Figure 1. Mirza Mohammad Bagher Mo'in-ol-Boka with his manuscripts among actors in costume. (Photo courtesy of Central Library of University of Tehran, 7th Album, Number 235)

Reza Kouchek-zadeh is a theatre scholar, author, playwright, dramaturg, and director based in Tehran. He holds an MA from the Tarbiat Modares University of Tehran. His research focuses on Iranian traditional performances and chronicling the history of ta'ziyeh. He teaches playwrighting, directing, and dramaturgy at several Iranian universities. r.kuochekzadeh@gmail.com

Milad Azarm is a Theatre PhD student in the School of Interdisciplinary Arts at Ohio University. As an author and director, he taught at Kamal-Ol-Molk University and the Drizhno University of Art in Iran. His writing appears in English and Persian academic journals.ma845717@ohio.edu 


\section{Shabih'khani and Shabih'gardans}

Scholars studying traditional Persian arts often do not conduct in-depth research on historical documents written in Persian. ${ }^{1}$ Many research efforts focused on these artistic traditions have been limited to non-Persian sources and observations, adding little to previous knowledge. Such is the case of studies of shabih'khani' (نبيهخو انى), also widely known as ta'ziyeh (تعزيه). Shabih'khani, one of several traditional theatre forms of Shi'a Islam, is a popular indigenous Iranian theatrical form. The earliest accounts of shabih'khani date from the 18th century, but the performance must certainly have developed centuries earlier, long before there was Iranian contact with Western theatre. It is therefore fully indigenous. Shabih'khani evolved into an elaborate and popular theatrical tradition on its own. ${ }^{3}$

The theatrical conventions of shabih'khani are not entirely unique. It is staged in the round and uses animals as well as human actors, but it is a fully realized drama, not circus. The actors - called shabib'khans (شبيهخوان), performers of shabib' (شبيه), which might be translated as "simulation," "mimesis," "verisimilitude," or "imitation" — perform holding in their hands individual character sides called tumar (طومار) or fard (فرد) in order to distance themselves from the roles they are portraying. This separation is necessary to protect performers from religious conservatives who may accuse the actors of engaging in idolatry by portraying human figures. ${ }^{4}$ Characters both declaim their lines and chant them using traditional virtuosic classical Persian musical modes. ${ }^{5}$ The scripts are highly literary, replete with Persian poetic structures. Each majles (مجلس), or play, ${ }^{6}$ is quite flexible: performances expand or contract based on time, occasion, venue, and audience reaction. These edits on the fly are built into the performance practice; they are anticipated by performers and by the director, the shabib'gardan. ${ }^{7}$ There are

1. This essay has been edited by Professor William O. Beeman.

2. Shabih'khani is an umbrella term for all forms of ta'ziyeh, including women's (شبيه زنان) and comedic (شبيه مضحك). For this article, we have modified the transliteration of shabih'khani. The term shabih' (شبيه)' means "imitation," "mimesis," or "verisimilitude." The term khani (خوانى) is correctly transliterated kh"āni or $x^{v} \bar{a} n i$, with a silent $\operatorname{vav}(\mathrm{g}$ ) after the initial consonant $(\dot{\tau})$, here transliterated as kh, and a long ā. Both the superscript v and the long ā have been omitted in the transcription for simplicity. Additionally, the letters qaf (ق) and ghein $(\dot{\xi})$, pronounced the same in most dialects of modern Persian, have been transliterated as either q or gh in proper names depending on convention in published works. All forms of the letters hamzeh (c) and 'ein (ع) have been transliterated with a single quote ('). The term ta'ziyeh derives from the Arabic triliteral root 'azza ( ع ( 1 ( ) and can be translated as "consolation." - All transliterations and translations from Persian are our own.

3. There are two sets of figures numbered throughout the article: those in print here and those only available online. Figure callouts indicating "in SM" can be found on the article's page at www.cambridge.org/TDR under the Supplementary Materials tab, along with the 3 tables noted parenthetically in the text. - Ed.

4. Peter Chelkowski, quoting Mayel Baktash, writes: "The Shia religious jurists approved tashabbuh, a theory of imitation of Hussein and the other martyrs. 'Whoever identifies with a group (tashabbuh) becomes a member of that group and participates in the merit accruing to its members' (Baktash 1979:102). Therefore, acting as Hussein becomes advantageous, but pretending to be Hussein is sinful. This gives impetus to the dramatic functions of the Hussein rituals" (1985:20; see also Yarshater 1979).

5. The Persian word khvāndan (خواندن), from which the term khvani (خوانى) is derived, can be translated as "read," "chant," "declaim," or "sing." For religious purposes, it is important that shabih'khani actors not be seen as "singers" because of the prohibition by conservative religious authorities against "music." In objective terms, however, these performers are some of the finest vocalists in the world, leading outside observers to occasionally identify shabih'khani as "Islamic opera."

6. The word "majles" (مجلس) may be translated as "assembly," but in the case of shabih'khani it is the equivalent of an individual play. We use "majles" in the titles of individual shabih'namehs. Shabih'nameh refers to the scripts of shabih'khani.

7. Shabih'gardan is Persian for the director of a shabih'khani. The term gardan refers to someone who sets something in motion. Other terms frequently used in this essay are shabih'nameh and majles, play or script; and shabih'nevis, playwright. 
no sets; the performance unfolds on a bare platform. The actors are elaborately costumed and use many props. They are exclusively male, with men taking women's roles, except when female shabi'khani is being performed. Young boys play children, both male and female. In these ways, shabih'khani conforms to the performance conventions of other traditional Iranian theatre forms. ${ }^{8}$ Casts are flexible in size: elaborate productions may have hundreds, modest productions only a dozen or so. This flexibility in all dimensions of the performance explains the need for an astute and authoritative shabih'gardan.

Information on shabih'khani including eyewitnesses, scripts, and other contemporary texts has been limited, incomplete, or wrong. Mistaken interpretations of these materials have often been replicated from one publication to another as scholars repeat past mistakes. ${ }^{9}$ Additionally, because performances of shabih'khani in modern times have focused on the martyrdom of the prophet Mohammad's (حضرت محمد) grandson, Imam Hussein (مام حسين), which took place in Karbala (كربلا) in current-day Iraq in 680 CE/59 SH/61 AH, ${ }^{10}$ there has been a tendency for scholars to treat the performance as a religious ritual, ignoring its clear identity as a theatrical performance. However, shabih'khani was always explicitly theatrical, whatever its themes and content. It has been especially difficult to piece together the evolution of shabih'khani during the Qajar era (عصر قاجار) (1789 to 1925 CE/1168 to 1304 SH). The bulk of contemporary academic papers are based on personal memories and observations from the 20th century. ${ }^{11}$

We rely instead on newly discovered, verified historical documents, most of which previously have not been accessible to scholars. ${ }^{12}$ These materials are archived in the Library, Museum, and Document Center of the Iranian parliament (LMDCIP) (مركز اسناد و كتابخانه مجلس). In addition, we have had access to, and have based our study on performance texts from, the Malek National Library and Museum of Iran (كتابخانه و موزه ملى ملى) and private collections. These new documents demonstrate the emergence of professional shabih'khani directors and dramaturgs in Iran during the rule of Naser al-Din Shah Qajar (1831-1896 CE/1209-1275 SH), here referred to as the Naseri period (دورنى ناصرى) (1848-1896 CE/1227-1275 SH). Our findings allow us to evaluate shabih'khani as something more than a traditional religious ritual expression. In fact, the shabih'khani tradition institutionalizes the role of the theatre director and the functions of the dramaturg prior to the emergence of such roles in Europe. We have uncovered evidence of these professions in Iran as early as the late 18th century.

The aforementioned newly discovered texts, including records of performances, manuscripts, annotations, and stage directions, center on the work of two renowned shabih'gardans - Mirza Mohammad Taqi Ta'ziyehgardan (ميرز امحمدتقى تعزيهكردان) (?-1872 CE/1250 SH) and Mirza

8. For additional information about contemporary shabih'khani/ta'ziyeh performances, see Beeman (1979, 1981a, 1981b, 1982, 2003, 2007, 2011, 2017); Beeman and Ghaffari (2005); Chelkowski (1979, 2005); Chelkowski and Ghaffari (2005); Ghaffari (1988); Homayouni (1971); Redden (2005); Shahidi (1979).

9. For example, while "Chelkowski notes that the adherents of Yazid might wear sunglasses to mark them as bad characters" (Beeman 1982:122), such points cannot be generalized to the Qajar era because there is no evidence of props like sunglasses in the lists of stage equipment or photographic images of that era (see also Thaiss 1973).

10. The Solar Hijri calendar, abbreviated as $\mathrm{SH}$, is the official calendar of Iran and Afghanistan. The Islamic/Arabic/ Lunar calendar is abbreviated as $\mathrm{AH}$.

11. Much of the contemporary literature about shabih'khani/ta'ziyeh is derived from Mohammad B. Ghaffari's memories as director of ta'ziyeh performances at the Shiraz Arts Festival (1967-1977) (see Beeman 2003; Beeman and Ghaffari 2005; Chelkowski and Ghaffari 2005; Redden 2005); and from spectators' observations of 20th-century performances, far removed from the Qajar Era.

12. The collection at the archives of the Library, Museum, and Document Center of the Iranian Parliament (LMDCIP) was used by the late Enayatollah Shahidi and Ali Bulookbashi for their book Ta'ziyeh and Ta'ziyeh'khani in the Qajar Era (Shahidi and Bulookbashi 2001). From 2005 to 2010, the collection was classified and published by the coauthor of this study, Reza Kouchek-zadeh (Descriptive list of Qajarian Shabih'namehs) (Kouchek-zadeh 2011, 2013). The collection was curated and classified for public display at the Iranian Artists Forum in 2019. 
Mohammad Bagher Mo’in-ol-Boka (ميرز امحمدباقر معينالبكا) (?-1914 CE/1293 SH; see fig. 1). "Mirza" means amanuensis or scribe. "Mo'in-ol-Boka" is a salaried court title meaning "Master of Weeping or Mourning." These two artists, and especially Mohammad Bagher, are the basis for this study.

Much contemporary scholarship on shabih'khani describes the work of a shabih'gardan as a kind of stage manager. In reality, the shabih'gardan is a director and shabib'nevis (شبيهنويس) is a Persian term for an author of a shabih'khani. The word "nevis" indicates a writer. There are no words for a dramaturg, but Mohammad Bagher can be considered a dramaturg in the contemporary sense of the term. Consequently, we will use the terms "director" and "dramaturg" for Mohammad Bagher, depending on the context.

\section{From Shabih' to Shabih'khani}

Peter Chelkowski, one of the most widely cited scholars of shabih'khani/ta'ziyeh, writes:

The first recorded public mourning ceremonies for Hussein took place in Baghdad in the fourth Islamic century. Sultan Muizz ad-Dawla of the Shiite Buyid dynasty ordered the markets closed on the day of Ashura, Muharram 10th, in the year 352 of the Muslim calendar (963 CE). Processions of Shiites circled the city while weeping, wailing and striking their heads in grief. The women were disheveled, and everyone wore torn black clothing. Hussein's murderers were soundly cursed. The Sunnis reacted with processions of their own in which Ali was denigrated for his defeat at the battle of "the Camel." This was re-enacted in the streets of Baghdad by costumed characters mounted on camels and horses. Bloody riots between the participants of these two opposing processions were recorded by historians even after the Shia Buyids. $(1985: 20)^{13}$

Chelkowski's account outlines the first steps in the development of public commemorations of the events of Karbala, namely, the emergence of the first processional performance of an Islamic historical event, paradoxically, enacted by Sunni Muslims rather than Shi'as. Chelkowski drew on the accounts of Mayel Baktash (Baktash 1969; see also Baktash 1979) and the historians Ali Ibn Al-Athir and Abu'l-Fedā EsmāI'l Ibn Kathir, who wrote "the Sunni Muslims, in commemoration of the Battle of the Camel (جنى جمل) and the defeat of Imam Ali (املى على), launched a procession with characters dressed as the historical Sunni Islamic personages Aisha, Talhah, and Zubayr ${ }^{[14]}$ (شبيه عايشه، طلحه و زبير) riding on camels" (Ibn Al-Athir 1972:44; see also Ibn Kathir 1988:312).

We can refer to these first processions as shabib'. From this point, these commemorative processions continued to evolve, eventually becoming a complete complex performance, shabih'khani or ta'ziyeh (تعزيه)..$^{15}$

The oldest known document reporting a full instance of a processional shabih' depicting the Shi'a account of the martyrdom of Imam Hussein is found in the German book Die Heutige Historie und Geographie (History and Geography Today) by Thomas Salmon and Matthias van Goch (1739), three years after the end of the Safavid dynasty (صفوى) (1501-

13. Ashura is the 10th day of the month of Muharram, the day when Imam Hussein, grandson of the Prophet Mohammad, was martyred at Karbala.

14. Historical characters fighting with Imam Ali, son-in-law of the Islamic prophet Muhammad and father of Imam Hussein.

15. The word shabih' (imitation) is more comprehensive than ta'ziyeh (Ale-Mohammed 2001:56). Here, the two terms are used interchangeably. "Ta'ziyeh, based on the Arabic root, refers to the concept of a mourning ceremony whereas shabih' or shabih'khani refer to its performance form [and mimesis]; ta'ziyeh is not used for non-tragic performances” (Baktash 1969:9). Ta’ziyeh refers to mourning for Imam Hussein or other Shi'ite Imams. But shabih' refers to all the manifestations of this traditional dramatic form including shabih'mozhek (شبيه مضحك) or comic performance (Anvar 2005:61; see also Anvar 1990). 
1736 CE/880-1114 SH) and at the start of the Afsharid dynasty (افنشاريان) (1736-1796 CE/ 1114-1175 SH) (Salmon and van Goch 1739:252). Salmon and van Goch report that this dialogueless processional shabih' had a greater number of theatrical elements than the one Ibn Al-Athir reported as the first shabih'. During the 766-year gap in records, we must assume that shabih' evolved from early dialogueless processions and visual tableaux of the events of Ashura (عانشورا) into fully theatrically realized shabih'khani. In its 18th-century rudimentary stage, as noted above, shabih' was a reenactment of the martyrdom of Imam Hussein, his family, and his followers in the battle of Karbala during the Islamic lunar month of Muharram, 680 CE. The battle and martyrdom were reenacted with the two sides - the martyrs and their attackers - visually differentiated by established signs and symbols. As Farokh Gaffary notes: "This must be the last stage of the lengthy evolution of a ritual before it becomes verbal and takes dramatic form" (1984:367).

"The Muharram ceremonies were flourishing and developing under the Safavid rule" (15011736 CE/880-1114 SH) (Chelkowski 1977:33), the first Iranian dynasty with Shi'ism as the official religion. Safavid officials supported Shi' ite mourning processions and encouraged the development of this new form of performative expression to advance their political goals and bolster their legitimacy (Aghaie 2004:12).

A full theatrical shabih'khani performance took place on Kharq Island (جزيره خارى) in the Persian Gulf in 1765 as described by Carsten Niebuhr, a German cartographer and explorer accompanying the 1761 to 1767 Royal Danish Arabia Expedition (Niebuhr 1778:199-200). Niebuhr witnessed the dramatic depiction of the martyrdom of Imam Hussein and his followers in what appears to be a fundamental majles that would evolve into the extensive body of complete separate dramas depicting individual episodes of the Karbala siege, battles, and martyrdoms. ${ }^{16}$

Twenty-two years after Niebuhr, in 1787, English orientalist and army officer William Francklin gave a full description of shabih'khani, including a scene where Imam Hussein's followers attempt to get water from the Euphrates River, triggering a battle. This majles included a detailed depiction of the marriage of Qassem (قاسم), Imam Hussein's nephew, and Qassem's martyrdom (Francklin 1790:249).

In the interval between Niebuhr's and Francklin's accounts, we can see how much the dramatic scope of the depiction of the events of Karbala had developed. The inclusion of the marriage and martyrdom of Qassem (Gobineau 1866b) ${ }^{17}$ is evidence of major additions to the stories performed in shabih'khani. While the main protagonist is always Imam Hussein, other characters became so important that even a peripheral figure like Qassem became the protagonist of a full shabih'khani majles. ${ }^{18}$ Based on secondary characters, many episodes of the Imam Hussein martyrdom saga were written as full-length majleses, with titles such as: A'roosi Qassem

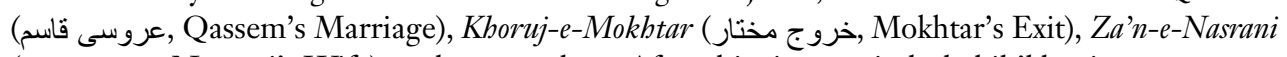
(زن نصر انىى, Nasrani's Wife), and many others. After this time period, shabih'khani was performed outside present-day Iran in Shi'a communities in Azerbaijan, Lebanon, Iraq, Bahrain, and elsewhere (Aghaie 2004; Jaffri 1979; Mervin 2007; Riggio 1994). Although the complete timeline of the transformation from "processional" or "tableau" shabih' to shabih'khani is not entirely clear (the time span is vast, from 973 to $1787 \mathrm{CE}$ ), it is definite that the theatrical

16. According to Niebuhr's description, it appears that he watched the majles 72 Tan (72 Bodies).

17. Count Joseph Arthur Gobineau published a full script of this majles, Les Noces de Kassem, in 1866 (see Gobineau 1866a, 1866b, 1866c, 1866d).

18. Although some scholars have considered Qassem, Ali Akbar, and many others as "primary religious figures" (Riggio 1994:121), "Hussein became the Shia standard-bearer and the symbol for courage in the face of tyranny" in Shi'a history (Stewart 2009:69). From the viewpoint of Shi'a believers, "Hussain was a noble historical religious character sacrificing himself to maintain truth” (Yeganeh 2010:145). Regarding Qassem’s ta’ziyeh see Homayouni (1973). 
tradition underwent an 817-year-evolution from processions, depictions, and mimicry to elaborate theatrical performances. This development accelerated immediately after the end of Safavid rule and "reached its peak during the Qajar period thanks, in particular, to the great interest and patronage shown by the Qajar Kings" (Anvar 2005:61; see also Calmard 1974, 1979).

Shabih'khani became an institutionalized feature of cultural life during the Qajar period, replete with professional artists who introduced innovations. Gradually, accounts of shabih'khani are found in the early scholarly work of Europeans, a limited number of eyewitness descriptions and collections of scripts (Gobineau 1866c; Arnold 1871; Chodźko 1878; Pelly 1879; Lassy 1916; Krymsky 1925; Litten 1929). The annotations and stage directions found in the documents we analyzed provide more valuable information about the innovations and the performance practices of shabih'khani. Annotated shabib'namebs ${ }^{19}$ (the scripts of shabih'khani) and other documents from the Qajar era provide much detailed information about these performance practices, making possible a historical analysis of the transformation and development of shabih'khani.

\section{Shabih'namehs of the Qajar Era}

Most traditional Iranian performance genres rely heavily on improvisation; for example, ruhozi (روحوضى) is a comic tradition without any written scripts (Beeman 1981a, 1981b, 1982, 2011; Floor 2005; Gaffary 1984:372). Shabih'khani is the sole traditional Iranian theatre form that relies on written texts, while retaining the same flexibility to expand or contract found in other Iranian performances.

A large number of Qajar shabih'namehs produced during the reign of Fath-Ali Shah Qajar (جكومت فتحعلىشاه قاجار ) (1772-1834 CE/1150-1213 SH) and subsequent rulers indicate a gradual transformation in line with the sociopolitical changes of the time. By studying extant manuscripts and tracing changes over time, one can gain insight into the minds of the creators of the Qajar era as shabih'khani evolved. Some developments included expanding existing stories, adding new stories, enhancing the roles of villains and antagonists - maokbalefkhans (مخالف in ان) in Persian - and streamlining for dramatic effect the dialogue of all characters. Most importantly, the evolution embodied a shift from a mournful, lamenting tone to a more heroic and epic representation of the stories.

Although a robust local printing industry began in the Safavid dynasty, printing spread more during the Naseri period (Afshar 1966:29). Publishing new books and republishing old ones such as Rawzat al-shubada (روضة الثهـا, Garden of Martyrs) ${ }^{20}$ motivated shabih'gardans to increase people's awareness of the martyrs' saga, especially the culminating events of Ashura the climactic day when Imam Hussein was martyred. Because most people were illiterate during this period, it was the performance of mourning rituals based on the new books and carried out by literate religious officials and eulogists that encouraged religious devotion.

Sociopolitical developments of the Naseri era also resulted in innovations among shabih'nevises and shabih'gardans, leading them to create better, well-composed shabih'khani performances. ${ }^{21}$ The influence of the Qajar rulers cannot be understated. As patrons they provided financial support and a more positive outlook towards the arts in general..$^{22}$ During the

19. The word nameh is a general term for a piece of writing.

20. "The form of these ta'ziyehs is based to a large degree upon al-Kashifi's Rawzat al-shuhada" (Cook 2007:132).

21. Some scholars believe that "Iran encountered modernity during the Qajar period" (Daryaee 2012:8) because of "the granting of the Constitution" (Yarshater 2001:194), the "founding the Dar al-Funun, Iran's first modem European-style institution of higher learning" (Ekhtiar 2001:153), the construction of the Indo-European telegraph line (Shahvar 2006), "the first systematic training for Qajar troops by European officers" (Ward [2009] 2014:67), and the introduction of European banking (Floor 1979).

22. The Qajar rulers relied heavily on arts to confirm and solidify their position (Ekhtiar and Sardar 2004). 
Naseri era, shabih'khani, which had previously been considered an avocation or a part-time occupation, became a much-respected profession. Financial evidence from documents of this period shows this transformation. In $1886 \mathrm{CE} / 1265 \mathrm{SH}$, the income of Mohammad Bagher and other shabih'gardans working in the Royal Theatre, the Tekyeh Dowlat (تكيه دولت), ${ }^{23}$ grew from a perfunctory monetary tip from the court into a full living wage (see fig. 1 in SM). ${ }^{24}$

There are several published collections of early shabih'namehs. These include the collection of Aleksander Chodźko, Théatre persan: choix de téaziés ou drames (manuscripts were purchased in 1833; Chodźko 1878); the collection of Wilhelm Litten, Das Drama in Persien (manuscripts dating from 1831 to 1834; Litten 1929); the collection of the Malek National Museum and Library of Iran (Kouchek-zadeh 2013); and the collection of Lewis Pelly (transcripts of performances from 1862 to 1873; Pelly 1879). Of special importance is the extensive 1,055-volume shabih'khani collection of Enrico Cerulli acquired while he was the Italian ambassador to Iran from 1950 to 1954 and deposited in the Vatican Library (Cerulli 1954, 1971a, 1971b, 1971c; Rossi and Bombaci 1961). The oldest majles from these collections was written in 1829 (Malik'pūr 2004:130-37). An inspection of these materials shows the clear evolution of the Iranian shabih'khani throughout the Qajar period.

Apart from these collections of shabih'khani manuscripts by Europeans, the newly discovered collections in the aforementioned Library, Museum, and Document Center of the Iranian Parliament (LMDCIP), retrieved and catalogued in 2010, ${ }^{25}$ give a better understanding of the Qajar shabih'namehs. The LMDCIP documents, written between $1831 \mathrm{CE} / 1210 \mathrm{SH}$ and the beginning of the Pahlavi era (يهلوى) (1925-1979 CE/1304-1357 SH), expand our knowledge of the texts of two prominent shabih'gardans and shabih'nevises in the Naseri period: Mirza Mohammad Taqi Ta'ziyehgardan (?-1872 CE/1250 SH) and Mirza Mohammad Bagher Mo'in-ol-Boka (?-1914 CE/1293 SH) (Kouchek-zadeh 2011). The relationship of these two shabih'gardans to each other and details of their lives and the workings of the Iranian theatre of that time have been, until now, shrouded in mystery.

Bahram Beyzai (بهر ام بيضايب), in his well-known work Namayesh dar Iran (نمايش درايران, Theatre in Iran), writes, "Maqtalnevises [متلعنويس, another term for shabih'nevis] never signed their texts, seeking divine rewards and not material ones" (1965:134). ${ }^{26}$ But the newly revealed documents, in LMDCIP and in other locations, reveal that a vast number of shabih'namehs include authors' names or pseudonyms incorporated in the verses. Therefore, it is wrong to assume that shabih' authors, in any time or position, did not sign their work. Indeed, the findings of the present study are based on annotations left by the authors (see fig. 2).

Apart from documenting contextual and structural changes from early shabih'namehs to more recent ones, our aim is to detect directorial and dramaturgical elements found in the LMDCIP documents used in performances: The sides, or tumar, held by performers during performances; fully compiled shabih'nameh scripts, called jong (جنگ); and handwritten annotations indicating stage directions found on both kinds of documents. None of the older

23. A tekyeh is a place where Shi'ite Muslims gather to mourn Muharram. Iranians had many tekyehs during the Qajar era. One of the most famous was Tekyeh Dowlat, which was constructed by the king's order. Tekyeh Dowlat means Royal Theatre. In general, a tekyeh is a theatre hall.

24. Images of Mohammed Bagher Mo'in-ol-Boka have been widely used by many scholars. However, we use pictures from original heretofore unpublished sources. In particular the images here of Mohammad Bagher's manuscripts have not been published previously.

25. Reza Kouchek-zadeh is the curator of the shabih'namehs archived in the LMDCIP, the oldest of which is from 1831.

26. There is a difference between the maqtalnevis and the shabih'nevis. The maqtalnevis chants elegies about the murders of Karbala. However, Beyzai uses the two terms interchangeably. The term maqtal refers to the place where the "killing" took place. Maqtal here refers to a place where Imam Hussein was killed. The maqtalnevis is someone who writes specifically about the moment of the killing of Imam Hussein. 


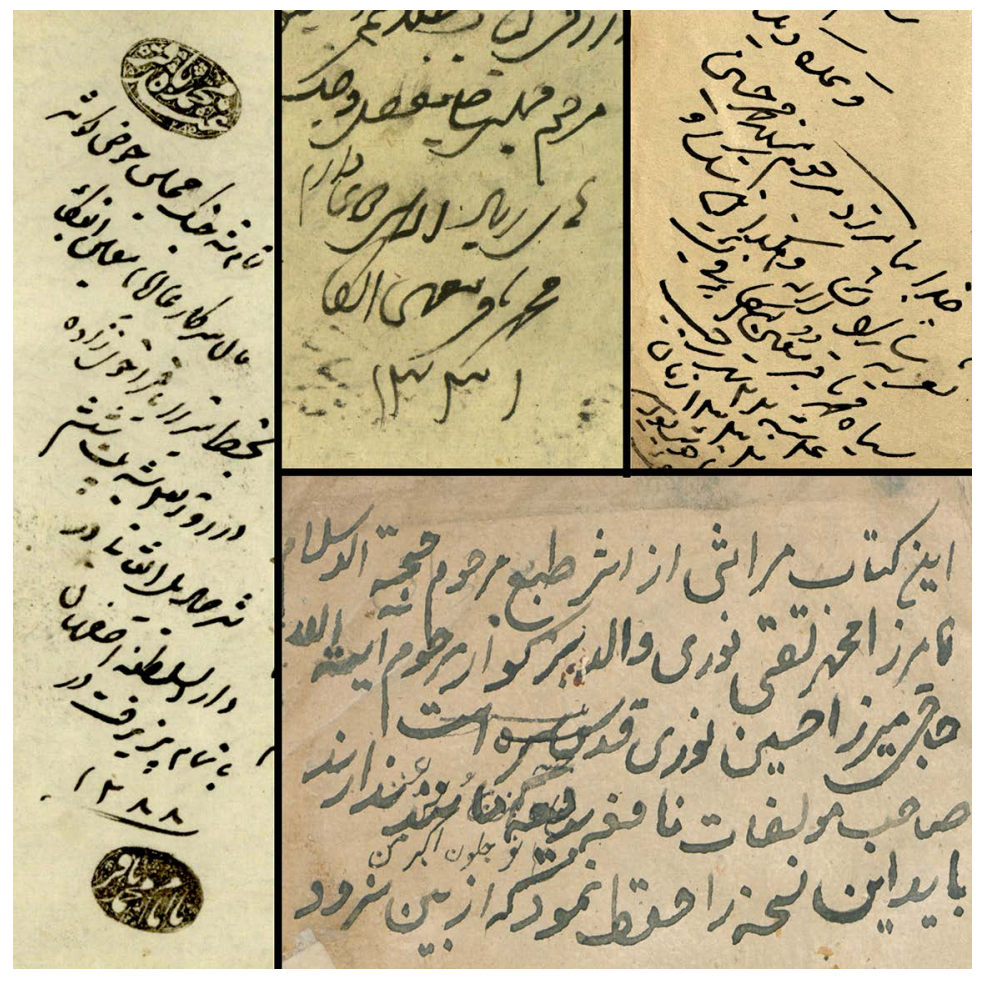

Figure 2. Author's name or pseudonym on four shabih'namehs. (Photo assemblage by Reza Kouchek-zadeh and Milad Azarm; photos courtesy of the LMDCIP archive) published collections mentioned earlier contain such annotations. These publications give only the names of characters and the dialogue in verse. But clearly, as the LMDCIP documents show, shabih'khani underwent a gradual transformation with director's notes and stage directions appearing alongside the dialogue. These notes show the theatrical knowledge of the shabih'gardans. For instance, signs of directing and dramaturgy can be seen in manuscripts 20411, 20383, 20347, 20279, $20213^{27}$ (see fig. 2 in SM). These are only a few examples out of hundreds.

Manuscript number 20324, majles Mabshar (مشش, The Day of Judgment), for example, is one shabih'nameh draft (see fig. 3 in $\mathrm{SM})$. It exists both in this draft form and in a polished rewritten final copy, both of which are

archived in the LMDCIP collection. As mentioned, shabih'nameh documents, produced before those in the LMDCIP collection, show no editing, director's, or dramaturg's notes.

Thus, though previously known primarily as authors of "mournful verse," the shabih'nevises gradually evolved into playwrights. Additionally, they evolved from being managers of shabih'khani troupes to well-informed professional stage directors. This creates a stark contrast to what has long been thought to have been their low-level managerial activities. Previously, shabih'nevises and shabih'gardans were considered devoted semiliterate producers of religious pageants rather than masters of deep theatrical knowledge. In this respect, Beyzai writes, "The poet - maqtalnevis - is not an expert or a scholar. He only conveys his feelings" (1965:131). However, the collection at the LMDCIP shows authors with sophisticated technical and artistic knowledge of theatre. The directors' notes in the LMDCIP collection are mainly written by Mirza Mohammad Taqi and Mirza Mohammad Bagher Mo'in-ol-Boka. Who were these artists?

\section{Mirza Mohammad Taqi}

Mirza Mohammad Taqi, the renowned shabih'gardan of Tehran, was raised to prominence during the reign of Mohammad Shah Qajar (محمششاه قاجار) (1808-1848 CE/1186-1227 SH) and in the early years of the Naseri era. His birthplace is believed to have been Isfahan, but he moved to Tehran to pursue shabih'khani as a profession (Shahidi and Bulookbashi 2001:710). He was the major shabih'gardan of Tekyeh Abbasabad (تكيه عباس آباد), the old Tekyeh Dowlat, or Tekyeh Haj Mirza Aghasi (تكيه حاج ميرزا آقاسى) as well as other famous tekyehs in Tehran. Old Tekyeh Dowlat, Tekyeh Abbasabad, and Tekyeh Haj Mirza Aghasi are different names for one place called the Royal Tekyeh, several years before the new Tekyeh Dowlat was built in 1868 CE/1247 SH (Amanat 1997:435). The new Tekyeh Dowlat was destroyed in 1947 CE/

27. Each number refers to a specific manuscript archived in the LMDCIP. 
1326 SH. The end of the Tekyeh Dowlat is well known, but there are many debates about the date of its inauguration. Based on the most recent book Memari Tekyeb Dowlat (معمارى تكيه دولت, Architecture of Tekyeh Dowlat; 2018) by Eskandar Mokhtari, professor of architecture at the Islamic Azad University of Tehran, Tekyeh Dowlat was constructed gradually, completed in 1879 CE/1258 SH. Basing his conclusions on Etemad al-Saltanah's notes, old maps of Tehran, and Sharaf Monthly (ماهنامه شرف), published during the Qajar era, Mokhtari finds that Tekyeh Dowlat's construction began in 1868. According to Sharaf Montbly, it was finished four to five years later (Etemad al-Saltanah 1887), which means it opened in 1872 or 1873 . Under the supervision of Bagher Ayatollahzadeh Shirazi (1936-2007), a famous architect and professor in Iran, a group excavated Tekyeh Dowlat's site near Golestan Palace in 1995. They found mosaics, one of which was dated 1879. Thus, work on Tekyeh Dowlat began in 1868, it was inaugurated around 1873, and its ornamentations were finished in $1879 . .^{28}$

Mohammad Taqi, who passed away in 1872, a year before the opening of the new Tekyeh Dowlat, is often referred to as a shabih'gardan or ta'ziyeh'gardan. However, in the LMDCIP collection, Mirza Mohammad Bagher Mo'in-ol-Boka, the younger shabih'gardan, refers to Taqi as a "master": "the great Mo'in" or "the late Mo'in-ol-Boka." Mohammad Bagher's high regard for Mohammad Taqi is reflected in referring to him this way, as seen in texts 20111, 20172, 20183 , etc. But none of the texts authored by Mohammad Taqi were signed with this honorific.

Abdullah Mostofi (عبداله مستوفى) (1876-1950 CE/1255-1329 SH), who witnessed many shabih'khani performances at the Tekyeh Dowlat, writes, "Mirza Mohammad Taqi arranged performances and by expanding their storylines, transformed ta'ziyeh from a performance for the masses to one worthy of the royals. [...] Anywhere he found a talented person, Mirza would follow him, and by force or promise, prepared that person for shabih'khani” ([1947] 1981:290). Enayatullah Shahidi (عنايت الله شهيدى) and Ali Bulookbashi (على بلوكباشى) also characterize Mirza Mohammad Taqi's dramaturgical work as editing verses into polished stage dialogue, incorporating renowned poems by Moghbel-e-sfahani (بقل اصفهانى), Bidel-e-hirazi (بيدل شيرازى), and Shahab Isfahani (ثهاب اصفهانى), and supporting authors of new shabihs with new stories (2001: 711). Mostofi further describes Mirza Mohammad Taqi's contributions:

This tragic opera [shabih'khani] also had a regisseur who acted as an orchestra conductor. He determined the clothes for each role. His other duty was to do preparation and arrange the mise-en-scène as was common with Europeans. [...He] educated the actors, teaching them proper gestures for each role, in order to make the performances appropriate for the king, which was one of his most arduous tasks. ([1947] 1981:291)

Several LMDCIP manuscripts were composed or edited by Mohammad Taqi. "Asrari” (اسر ارى), the pseudonym associated with him by Shahidi and Bulookbashi, is inaccurate. In a large number of verses written by Mohammad Taqi as well as in his dramaturgical work, he referred to himself as "Fadayi" (فدايى). ${ }^{29}$ Shahidi and Bulookbashi mistakenly attribute the title of Fadayi to Mohammad Bagher, Mohammad Taqi's successor, but "Zabihi" (ذبيحى) is the correct pseudonym for Mohammad Bagher. His annotation on the margin of the text Mabshar ( محى "مشيحر, The Day of Judgment), manuscript 20436, clearly reads, "Composed by humble servant, Mohammad Bagher Ta'ziyehsaz-bashi ${ }^{30}$ also known as Mo'in-ol-Boka, pseudonym 'Zabihi'” (Kouchek-zadeh 2011:300) (fig. 3).

28. For more information about Tekyeh Dowlat see Etemad al-Saltanah (1887); Shahidi (1999:37-101); Mokhtari (2018); Rahimi (2013:55-71).

29. A devotee who sacrifices his life for his faith.

30. Ta'ziyehsaz in Persian (saz, "builder, constructor") means someone who creates a ta'ziyeh. It can be used as a reference to both a shabih'gardan and a shabih'nevis. It should be noted that except for titles, only given names were used in Iran. Family names were first introduced in Iran during the Pahlavi regime (1925-1979 CE/1304-1357 SH). 


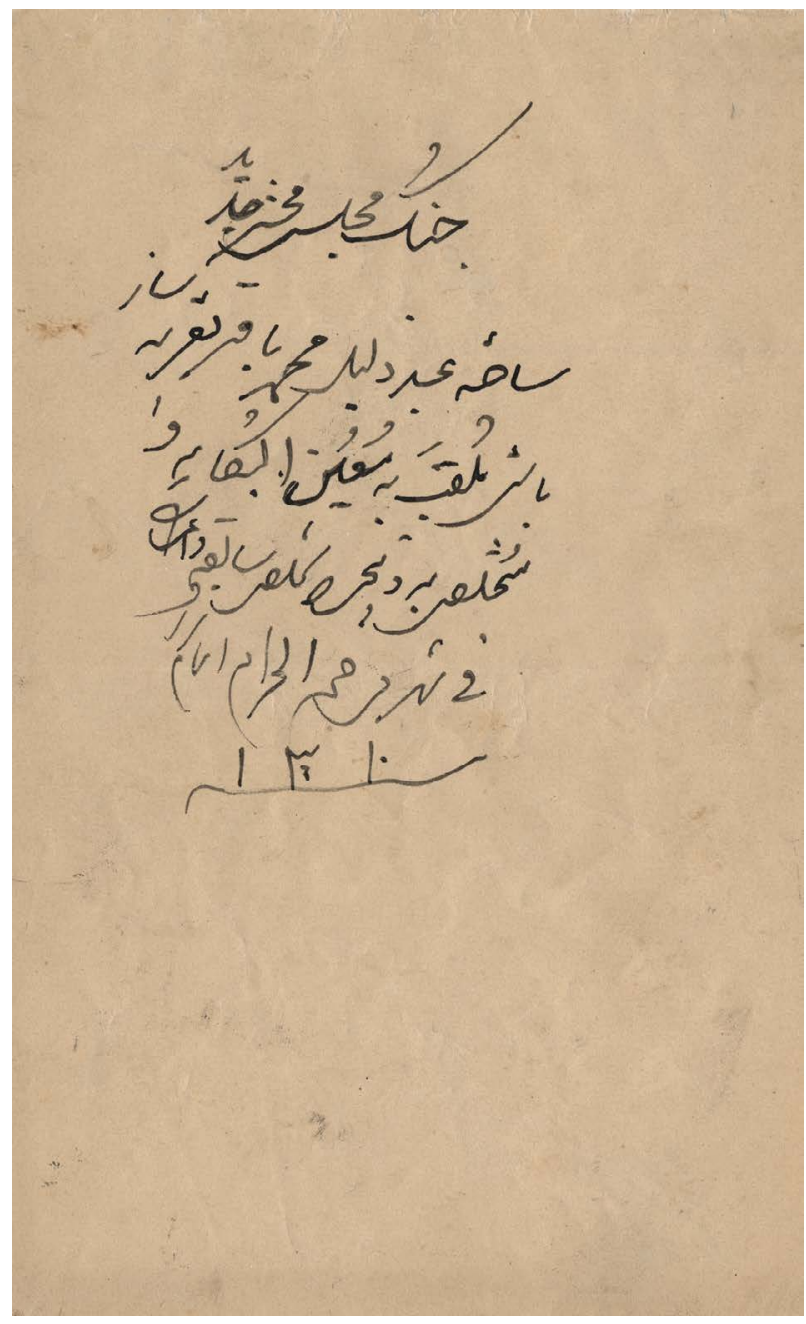

Figure 3. Mirza Mohammad Bagher's side note on the text of Mahshar (محشر جديد, The Day of Judgment). (Photo courtesy of the LMDCIP archive)
As further evidence, in manuscript 20157 , written in 1833 , the pseudonym for Mohammad Taqi appears in the last verse where he asks the Almighty for blessings, "Grant my prayers for a lengthy life / Grant all Fadayi's wishes!" (in Kouchekzadeh 2011:150). Mohammad Bagher confirms his identity by adding a line that reads, "Hand-transcribed by Mo'in-ol-Boka; accurate." This famous annotation was, we believe, not Mohammad Bagher's statement of authorship, but rather a written confirmation of the accuracy of these texts, using his official title: "Mo'in-ol-Boka." This annotation appears on both old and new shabih'namehs that were written by authors other than him. Also, the dates of the texts composed by "Fadayi" are closer to the period Mohammad Taqi was active. Therefore, it is safe to assume that Fadayi is the pseudonym for Mohammad Taqi, while Zabihi is Mohammad Bagher's pseudonym. As noted, Mohammad Taqi passed away in 1872 , the year before the opening of the famous Tekyeh Dowlat, the court-sponsored theatre-in-the-round where shabih'khani was presented during the latter half of the 19th century. As photography at the time was used solely for family members of the royal court, no photo of Mohammad Taqi is known to exist. On the other hand, we have photographs of Mohammad Bagher (fig. 4).

\section{Mirza Mohammad Bagher}

Mo'in-ol-Boka Mohammad Bagher, using the pseudonym Ta'ziyehsaz-bashi (تعزيهسازباشى), started his career assisting Mohammad Taqi while at the same time composing verses. We

do not know the exact date when Mohammad Bagher began his work. During the Qajar era, most jobs were inherited (Tajbakhsh 1998:425). Male children apprenticed with their grandfathers, fathers, or uncles. As Mohammad Taqi's nephew, Mohammad Bagher learned stagecraft and management from his uncle. Before being granted the formal title Mo'in-ol-Boka, Mohammad Bagher used his pseudonymous title, Ta'ziyehsaz-bashi, in manuscript 20436. So most probably during his childhood he was his uncle's scribe and assistant. According to sources such as Mostofi's Description of My Life (شرح زندگانى من) ([1947] 1981), Mohammad Bagher was mistakenly thought to have been the son of Mohammad Taqi. This mistake found its way into publications such as Beyzai's Theatre in Iran (1965). Most interestingly, the Qajar king Naser al-Din Shah — who appointed the director of Tekyeh Dowlat — in his daily notes after watching

31. Roughly "head ta’ziyeh creator." The term bashi (باشىى) is a Turkish term meaning "head.” There is no evidence that this was an official court title. 
a performance during Muharram 1885 CE/1264 SH, writes, "this troupe was that of Mohammad Taqi's son" (Qajar 1999:234). This may have reinforced the mistake. It is understandable the two men were assumed to have been father and son given their close mentor-protégé relationship. In LMDCIP manuscripts 20111, 20172, 20183, 20266, and 20389, Mohammad Bagher refers to himself as Mo'inol-Boka's nephew, giving his uncle the title he himself later assumed. In manuscript 20111, Mohammad Bagher clearly refers to himself as "Mohammad Bagher, son of Mohammad Bagher, the late Mo'in-olBoka's nephew."

Perhaps it is because of these flattering, personally applied honorifics in a number of sources that the title Mo'inol-Boka has been mistakenly attributed to Mohammad Taqi rather than Mohammad Bagher by later scholars. In one authoritative source, Almaa'ser-o val A'sa'r (المآثر و الآثار), written by Qajar court official Etemad al-Saltanah (اعتماد السلطنه), Mohammad Bagher is clearly identified as Mo'in-ol-Boka (Etemad al-Saltanah 1889:240). In addition, there are no records of the Qajar ruler Naser al-Din Shah granting a royal title to

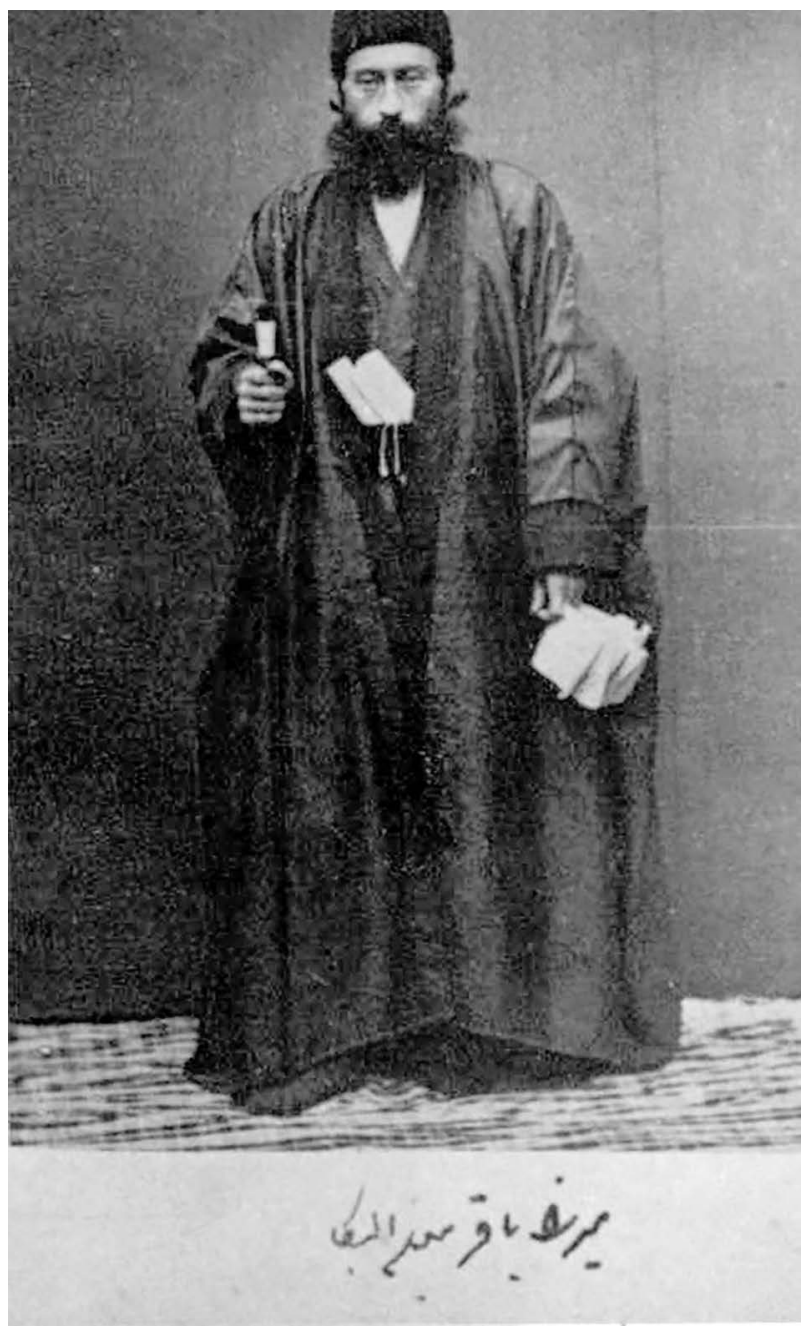

Figure 4. Mohammad Bagher Moin-ol-Boka wearing his formal costume, equipped with his directing tools: manuscripts in his hand and waist scarf, wooden cane in his other hand, and a hat he used for signaling. (Photo courtesy of the Central Library of the University of Tehran, 7th Album, Number 227) Mohammad Taqi. Considering the fact that it was highly uncommon for those with royal titles to be referred to by their birthnames, it is noteworthy that Mohammad Taqi is never referred to as Mo'in-ol-Boka by the Shah but rather as Mohammad Taqi or Mohammad Taqi Ta'ziyehgardan.

In photographs of Mirza Mohammad Bagher Mo'in-ol-Boka, whether during a shabih'khani or in group pictures, he is always seen holding a manuscript (see figs. 4, 6, 7, and 8). These manuscripts are likely sides rather than full scripts. One can assume that these sides are from the shabih'namehs being performed under his direction. Perhaps he wanted to assure his legacy as the preserver of shabih'namehs. This practice, incidentally, simplifies the task of identifying him among several photographs of shabih'khani performances of the era.

Among Mohammad Bagher's significant contributions was collecting, preparing, and editing majleses composed by Mohammad Taqi. By doing so, Mohammad Bagher safeguarded these manuscripts for future generations. Mohammad Bagher also collaborated with 


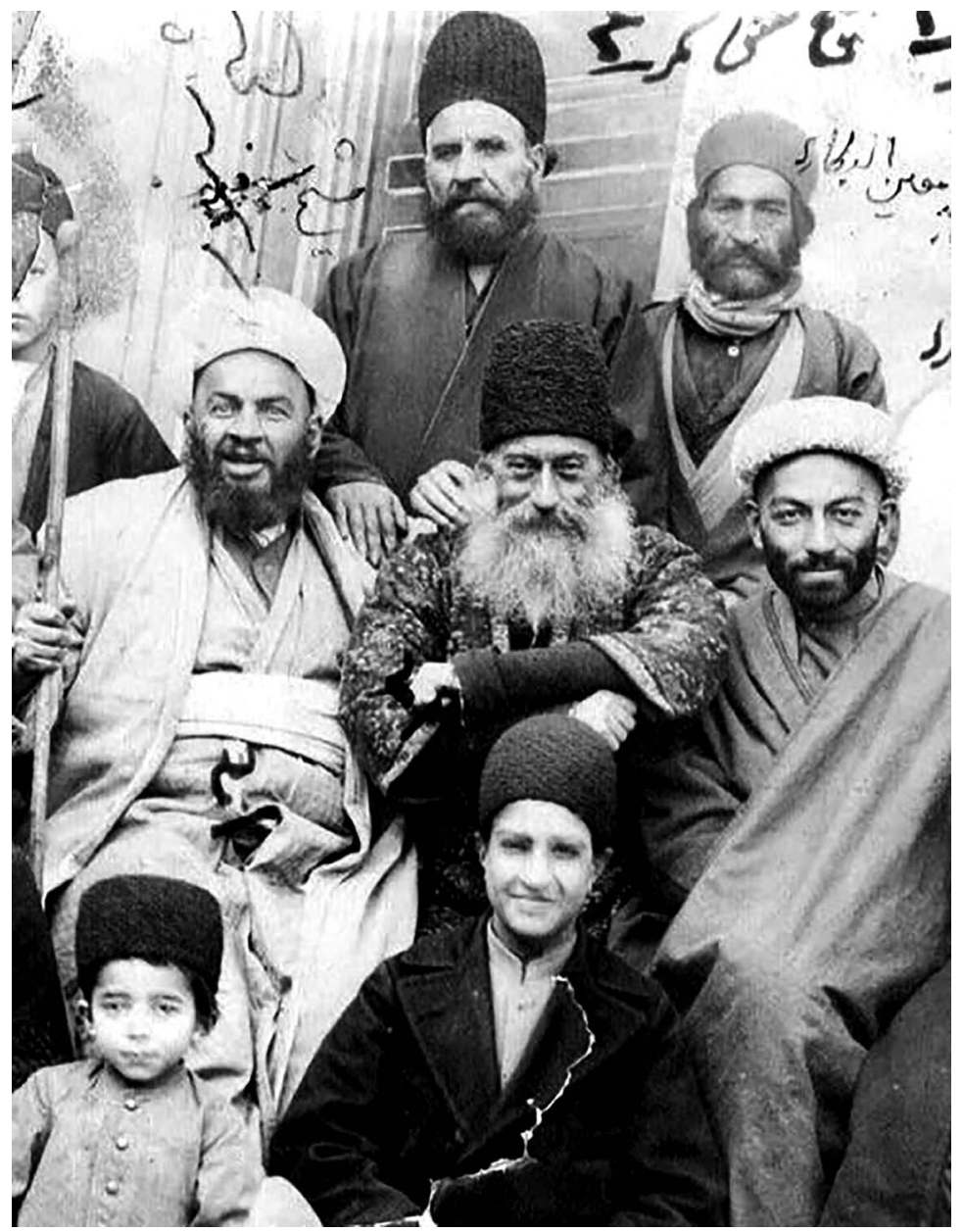

Figure 5. Center: older Mohammad Bagher. (Photo courtesy of the National Library of Iran)

prominent shabih'nevises of his time in composing and editing existing and new plays. It is thanks to such efforts that manuscripts from Tekyeh Dowlat performances were complete and accurate.

Mohammad Bagher also did the dramaturgical work of analyzing, annotating, and correcting defects in earlier shabih'namehs, adding technical commentary or suggesting improvements. During his time, shabih' moz'hek (مبيه) مضحى), a new comedic form of shabih'nameh, emerged. It is probable that Mohammad Bagher's theatrical knowledge contributed to the development of the form. An example, Shast Bastan Div (شست بستن ديو), Shackling the Demon), is in the LMDCIP collection, manuscript 20241. Shast Bastan Div was performed at the Isfahan Festival of People's Culture, or Jashn-e Farhang-e Martyrdom (جشن فر هنى مردم), in 1977. In

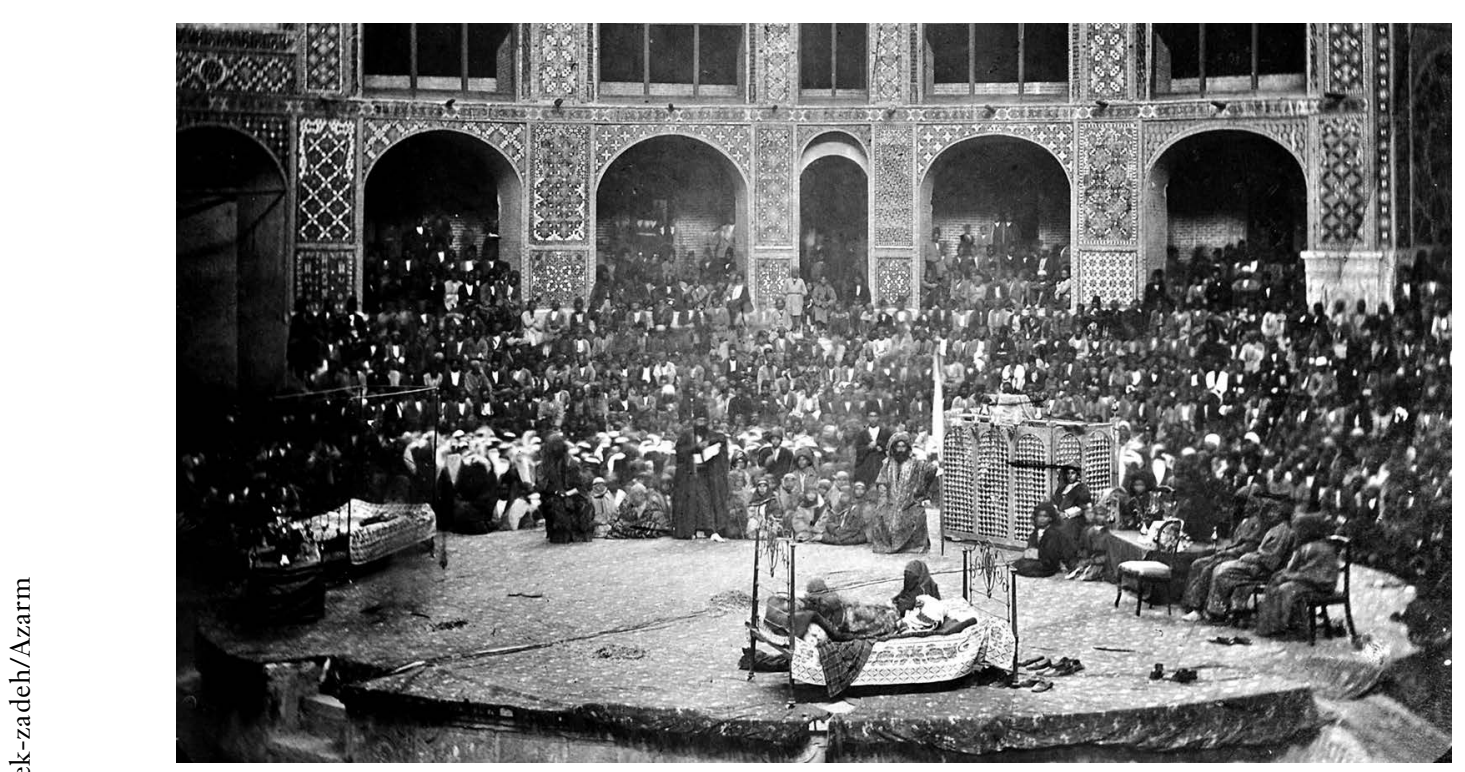

Figure 6. Mirza Mohammad Bagher Mo'in-ol-Boka (center) with manuscripts in hand during a shabih'khani in Tekyeh Dowlat. (Photo courtesy of Golestan Palace, 391st Album) 


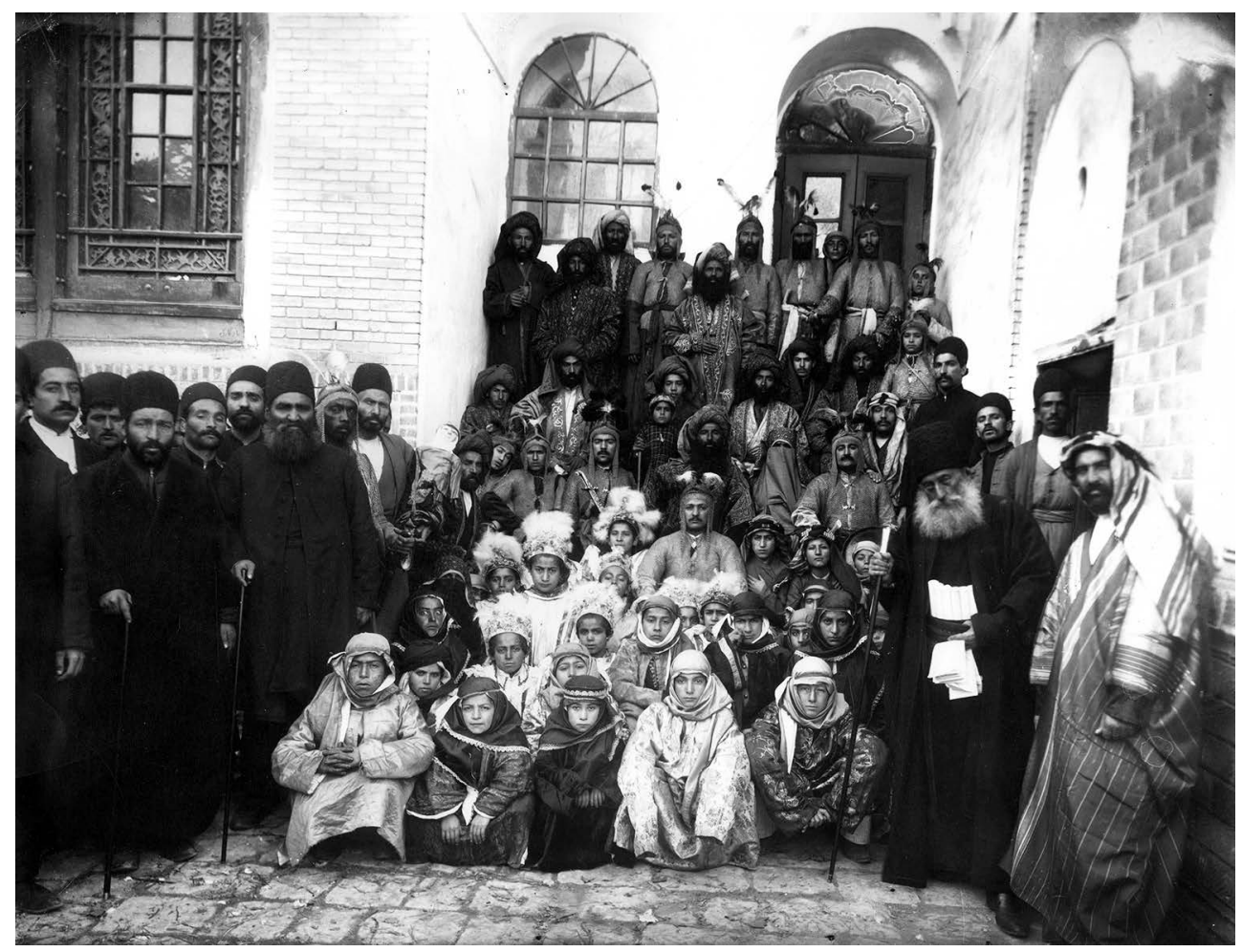

Figure 7. Mirza Mohammad Bagher Mo'in-ol-Boka (standing, front, second from right), shabih'nameh in hand, with his cast after a performance in Tekyeh Dowlat. (Photo from Moayer-ol-Mama'lek 1983:146)

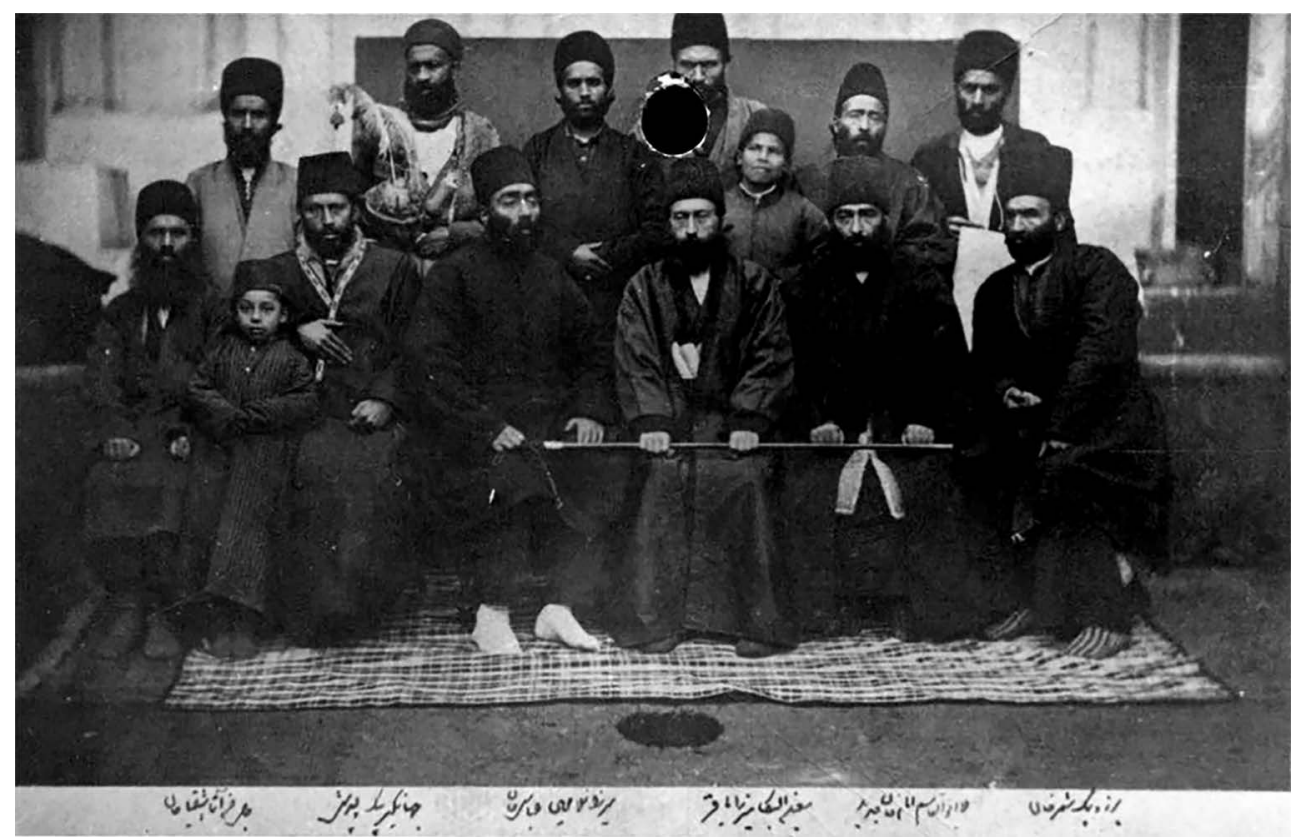

Figure 8. Mirza Mohammad Bagher Mo'in-ol-Boka with his ever-present wooden cane in hand and manuscripts in his cummerbund. Like a Western orchestra conductor, he used his cane to lead the musicians and direct the movement of actors onstage. (Photo courtesy of the Central Library of the University of Tehran, 7th Album, Number 238) 
this play the people are terrorized by a demon. They call on the child Ali-cousin and future son-in-law of the Prophet Mohammad, and later the father of Imam Hussein - to help them. Ali ties the thumbs of the demon together, immobilizing him. Ali then makes the demon recant his evil ways. The demon is a comic figure. One of the highlights of the performance is when Ali mounts the demon as if he were a horse and makes him do humiliating tricks.

Eugène Aubin, a French diplomat who visited Persia in 1906 CE/1285 SH and 1907 CE/ $1286 \mathrm{SH}$, writes in his travel journals:

Mo'in-ol-Boka manages the stage. He, an old man with a white beard, first introduces himself [or the subject of the majles] to the audiences. He wears a long cloak and carries a wooden cane along with many paper scrolls in his waist shawl. Each paper is one of the roles in the ta'ziyeh. He has been administrating the royal ta'ziyeh for 37 years [...]. $(1908: 170)$

Assuming that Aubin's records are accurate, and taking into account the difference between the lunar and the Western calendars, Mohammad Bagher began his professional work in 1871. Because Tekyeh Dowlat was built in 1868 and inaugurated in 1873, Mohammad Bagher must have started his work in the old Tekyeh Dowlat or Tekyeh Abbasabad known as Tekyeh Haj Mirza Aghasi, which carried the name "Royal Tekyeh" before the opening of Tekyeh Dowlat. Mohammad Taqi's ill health and eventual passing in 1872 might have led the patrons of Tekyeh Abbasabad to replace Mohammad Taqi with Mohammad Bagher.

A year or two after the short tenure of another shabih'gardan, Mosatafa Kashani (Boozari 1978:27-28), ${ }^{32}$ Mohammad Bagher became the sole royal shabih'gardan. Mohammed Bagher's theatrical knowledge and expertise even exceeded Mohammad Taqi's, whose innovations left a clear mark on shabih' performances. About the pivotal influence of Mohammad Taqi and Mohammad Bagher, Aubin writes, "This father and son have played an important role in the formation of the contemporary ta'ziyeh and other religious performances" (1908:171). (Of course, as noted, their relationship was actually uncle-nephew.) Aubin reports that Mohammad Bagher had a formal position in the royal court, as indicated by his name, Mo'in-ol-Boka. During the month of Ramadan, he selected the best singers and musicians from Tehran and other parts of Iran and secured four-month contracts with them (Aubin 1908:171). The abundance of Mohammad Bagher's manuscripts in the LMDCIP collection is a testament to his endeavors developing the shabih'nameh.

The date of Mohammad Bagher's passing is not certain. According to Ali Javaherkalam, it was $1908 \mathrm{CE} / 1287 \mathrm{SH}$. "On a rainy night, the roof of his house collapsed, and his wife and children perished. He miraculously survived but suffered mentally for a few months and died of heartbreak" (Javaherkalam 1965:11). But in Abdolhossain Sepehr's Mer'at-ol-Vaghaye Mozafari (مر آت الوقايع مظفرى), Mohammad Bagher died in 1905 CE/1284 SH: "On the 20th of Rabí'alawwal [25th May], Gholamali Semsar (غلامعلى سمسار) went to Mirza Mohammad Bagher Mo'in -ol-Boka to ask for his wages. Mo'in-ol-Boka was asleep so Gholamali calls out his name. When he steps out, the roof of his house collapsed killing his wife, sister-in-law, and six-year-old son" (Sepehr 2007:779). But there is some evidence that Mohammad Bagher was alive in 1914. In the collection at the LMDCIP, there are two shabih'namehs with Mo'in-ol-Boka's signature, Khoruj-e Mokbtar (خروج مختار, Mokhtar's Exit) (20193) and Mokbleb va Shabadate Ghanbar

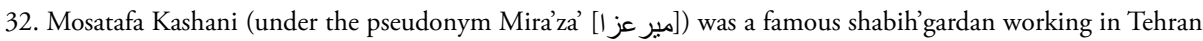

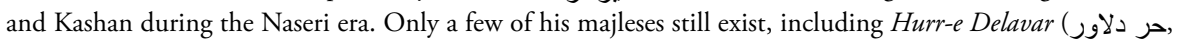
Courageous Hurr) (Sayyad 1971) and Shimr va Abbas (شمر و عباس, Shimr and Abbas) (Beyzai 1962:26-39). "Mira’za' was highly talented in composing poems, nohas (نوحساش, laments about Islamic martyrs), and pishkha'nis (بيش خو انىى, opening poems of a majles). Most dulcet pishkha’nis of Kashanian and Tehranian ta'ziyeh's were composed by him" (Shahidi and Bulookbashi 2001:711). 
مخلب و شهادت قنبر) Mokhleb and Martyrdom of Ghanbar) (20440) (see figs. 4 and 5 in SM). It is highly probable that these two are his last shabih'namehs. Another possible last play is Vafate Maryam (وفات مريم, Mary's Passing) (20540), an unfinished shabih'nameh that is not completely his work, as he notes on the manuscript, "May God bless Seyed Mohammad Hussein Ta'ziehsaz and me, a humble servant, Mo'in-ol-Boka on 22nd Rajab 1332 [16 June 1914 CE $/ 25$ Khordad $1293 \mathrm{SH}$ ], while in ill health" (fig. 9). Based on such evidence, Mohammad Bagher's passing must have been soon after 1914. A newly discovered note by Sayyed Jalal al-Din Tehrani (سيد جلالالدين تهر انى) (1896-1987 CE/1275-1366 SH), indicates that Mohammad Bagher was alive around $1920 \mathrm{CE} /$ $1299 \mathrm{SH}$ (see fig. 6 in SM). We do not know if this is true.

\section{Early Signs of}

\section{Theatre Directing} in Shabih'namehs

Analysis of the accounts of non-Iranian travelers, as well as the autobiographies, daily notes, and reports from foreign counsels mentioning Iranian shabih'khani, makes it clear that these non-Iranians generally lacked substantial theatrical knowledge of Iranian performance traditions. What is

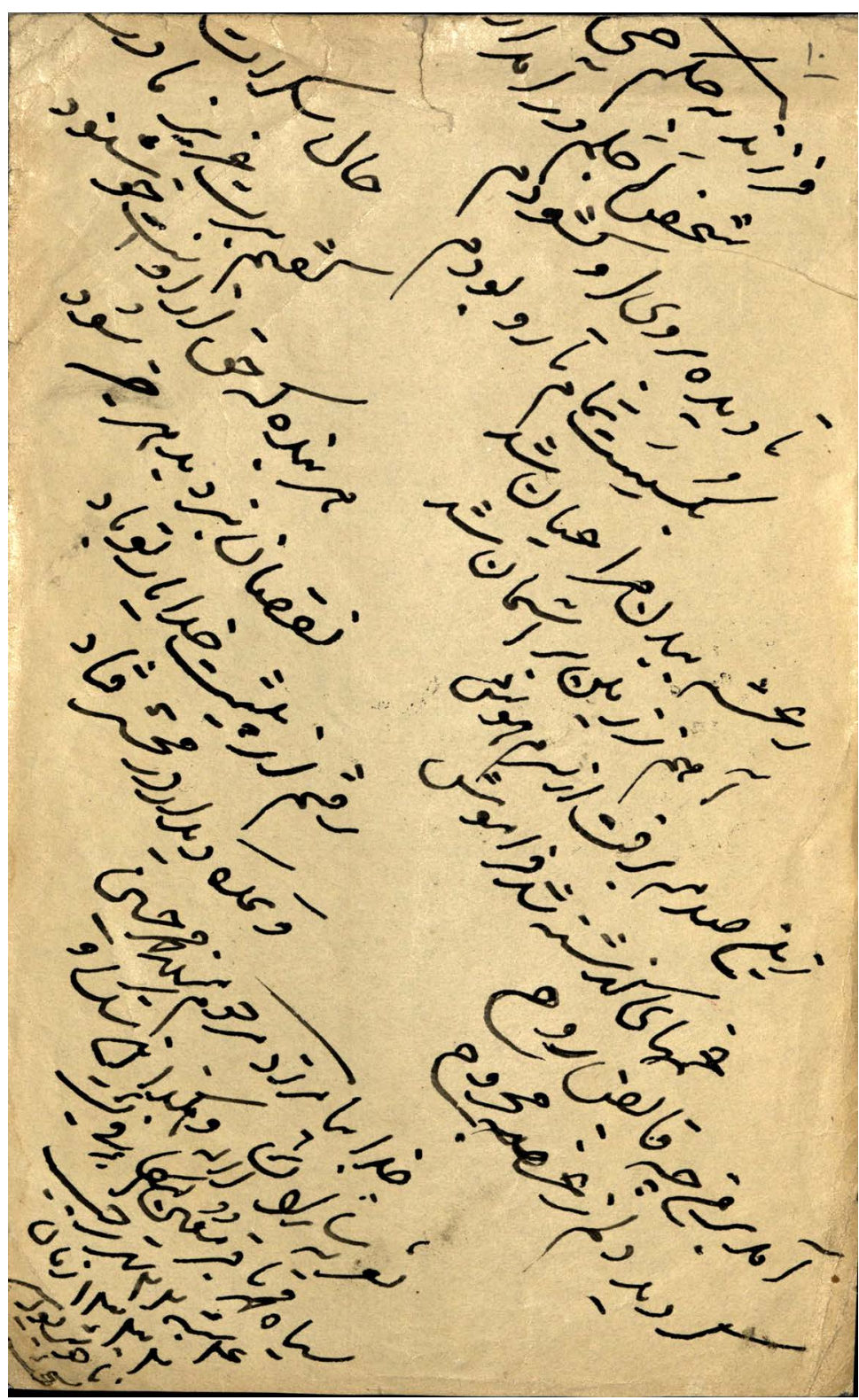

Figure 9. Handwriting of Mohammad Bagher at the end of Vafate Maryam (وفات مريم, Mary's Passing), manuscript 20540. (Photo courtesy of the LMDCIP archive) recounted is astonishment and awe for this unfamiliar form of performance, or at best, an anthropological assessment of what they regarded as Iranian folklore. As Jamshīd Malik'pūr notes,

[Most] writings on the ta'ziyeh were not written from a theatrical viewpoint and as a result, they did not attract the attention of most Western theatre specialists. It was not until 1970 that the ta'ziyeh became known to Western theatre scholars. Peter Brook, after seeing a ta'ziyeh performance in that year, expressed his enthusiasm for its theatrical qualities. (2004:2) 
Lack of attention to theatrical details in these 19th- and early-20th-century observations may also be explained by the fact that shabih'gardans were not in the habit of communicating their methods either verbally or in writing. Much in line with Eastern artistic practice, the shabih'gardans and shabih'nevises regarded the path to artistic expression as more valuable than the destination. The present was treasured more than future rewards; these artists shunned any form of recognition. The absence of any specific records detailing shabih'khani directing makes the newly found texts the only source to identify, even if only indirectly, the Iranian conception of theatre directing.

Signs of directing — of how to stage and perform the plays — can be classified into two groups: within the dialogue of the plays themselves, and outside the plays. While some directing can be hidden in subtexts, such as acts and movements implied by the dramatic action, others are written in annotations alongside the dialogue.

In general, a play text consists of dialogue and, sometimes, stage directions. Both of these can be discerned through analysis of shabih'namehs and evaluated by comparing the texts from different historical periods. Annotations written in the margins of the dramatic dialogue are particularly important for showing the growing importance of the director's role over time. This is particularly evident in the LMDCIP shabih'khani manuscripts as opposed to manuscripts from the earlier Naseri period where there are no annotations.

Certain manuscripts in the LMDCIP corpus contain annotations that are directors' notes that later evolved into concrete stage directions. Shabih'namehs of the Qajar era contain vivid, extensive descriptions, as in this annotation in manuscript 20206, which specifies a circumambulation of the stage:

Mr. Ali Akbar wearing armor enters riding on a horse. Goes around the stage once and exits. Then, the girl [...] stands up swiftly. [Ali Akbar] gets off the horse. From a distance, he looks at her and walks slowly towards her. He then stops behind her and starts executing his role. (in Kouchek-zadeh 2011:140; see fig. 7 in SM)

As William O. Beeman notes, speaking of contemporary shabih'khani: "movement in an arc or circle depicts a long journey; movement in a straight-line indicates actual distance" (Beeman 2003:11). Traveling in an arc also indicates the start of a battle or increasing tension. "Scene changes are indicated when a performer circles the platform" (Chelkowski 2005:17). These stage conventions are familiar to Iranian audiences. Indeed, such conventions seem to have evolved from the stage directions and directorial tools shabih'gardans used to control actors' movements and provide scenic contexts without sets.

Similarly, in manuscript 20252:

Moses looks from in-between his two fingers. Drumbeats are heard. Imam enters and sits. Shimr blows his horn. Then, Imam starts to sing. Imam Hossein wakes up. [Zaynab] kisses his throat. Ruqayyah takes the bridle and walks around [the stage]. (in Kouchekzadeh 2011:171; see fig. 8 in SM)

"Looks from in-between his two fingers" is a characteristic stage gesture unique to shabih'khani. It is a signal indicating supernatural vision. "This theatrical device known as a guriz" is a tool the director uses to indicate travel across space and time without changing sets (Riggio 2005:104). "Through the guriz, all ta'ziyeh drama expands beyond spatial and time constraints to merge the past and present into one unifying moment of intensity that allows the spectators to be simultaneously in the performance space and at Karbala" (Chelkowski 2005:23).

In manuscript number 20303, Shahadate Ghanbar va Mokbleb (مجلس شهادت قنبر و مخلب, Ghanbar and Mokhleb's Martyrdom), Mohammad Bagher writes: 
[Mokhleb] changes his turban. Mother answers. When they want to bury Mokhleb's son between two walls, [Mokhleb's wife] sings. After Imam's verse, followers sing chavooshi. (in Kouchek-zadeh 2011:204) ${ }^{33}$

Written annotations such as these indicate that the shabih'nevises were well aware that they wrote not literary pieces but dramatic texts. In addition to dialogue, they specified actions and movements to create fully realized theatrical scenes. In manuscript number 20374 , also by Mohammad Bagher, the annotated marginal notes read:

The Kaiser enters riding a horse. A group wearing European clothes enters with a wooden pallet, bells, instruments, sweets, fruits, etc. They place all on the pallet. After that, Hatef sings; the church people fall asleep. Another group, Armenians, come with a pallet [along with] bells, sweets, and fruit. After placing them on a tray, Hatef starts speaking. Malikeh goes to sleep. Malikeh turns around and kisses his hands. (257)

Similarly, in manuscript 20307 by Mohammad Bagher:

Approaching the Imam on a horse, Ibn-e-Shadad sings to him. Moslem laments on the Prophet's grave. While he sings, Moslem rides a horse one round [a full circle], and stays still. Drumbeat. He gets off the horse and sits by the water. Moslem writes a petition. [Qeys] rides towards Imam. Qeys gets the message and rides to Moslem. Moslem sings while riding on the horse one round. The hunter shoots an arrow. And then Moslem sings. Moslem gets off the horse. (207)

In the majles Za'n-e Nasrani (زن نصر انى, Nasrani's Wife), manuscript 20225, the marginal comments describe what happens:

The slave woman prepares the bed. She brings a pitcher. The Christian wife wakes up, walks outside barefoot. Fatimah goes over to the corpse of Abbas. The Christian wife speaks over the corpse of the Imam. The slave woman talks to the corpse of the Imam. Fatimah makes a speech next to the Euphrates River. (153)

The shabih'nevis, who was often also the shabih'gardan, was well aware of what was needed to make a successful theatrical performance. In the manuscripts, he wrote notes on acting and movement to complement the dialogue. In other words, in addition to literary, religious, and musical knowledge, a shabih'nevis was required to have expertise in how to perform. As a shabih'gardan, his main focus was to harmonize the text and the performance, to know what were the most effective gestures, staging, music, costumes, and props. In a large number of the annotations, words such as "instantly," "immediately," "exit," and "enter" and phrases such as "turn once around," "turn once around and sing," "turn once around and exit," "go around the bed and then sing," "go around, wake up," and "fight and leave" are frequently found (in Kouchek-zadeh 2011:106, 139, 153, 189, 210). Their main function is to create and control the rhythm of the performance. Such annotations determining the actors blocking and other directorial instructions were mainly in jongs, the full scripts. Jongs were used only by shabih'gardans, while the actors were given only the tumar, the sides.

\section{Western Theatre and Shabih'khani}

It may be tempting to suggest that the directorial functions in shabih'khani were borrowed from or influenced by Western theatre. However, the timeline of both traditions excludes this possibility. The annotations and stage directions written on shabih'khani texts date to before

33. Chavooshi is a type of melody within the Persian classical music dastgāh system. Dastgāh (دستخاه) is a musical modal system in traditional Persian art music. Persian music consists of 12 principal musical modal systems or dastgāhs (Farhat 1990; see also Beeman 2007). 
$1871 \mathrm{CE} / 1250 \mathrm{SH}$, years before the staging of the first European-style theatre in Iran. The first European style proscenium stage in Iran was in the Dar ul-Funun school's hall (Tama'sha'kha'ne Dar ul-Funun, تماثشاخانه دار الفنون) from 1886 to 1891 CE/1264 to 1270 SH.

The first European-style plays in Iran were written by Mirza Fatali Akhundov (ميرزا فتحعلى آخوندز اده, known as Akhundzadeh in Iran; 1812-1878 CE/1191-1256 SH), a pioneering playwright of the Azeri Turkic language. His plays were first translated into Persian after $1871 \mathrm{CE} /$ 1245 SH by Ja'far Gharachehdaghi (ميرز اجعفر قراجهداغى). Some of Akhundov's works, such as Moosio forda'n (موسيو زوردان, Mr. Jordan; 1872 CE/1250 SH) and Mola Ibrabim Khalil Kimiyagar (ملا ابر اهيم خليل كيمياكر, The Alchemist Mola Ibrahim Khalil; 1871 CE/1249 SH), seem to have been inspired by the comedies of Molière. Gharachehdaghi's preface to the published Persian translations of Akhundov's plays indicates that they did not attract large audiences. At about the same time, starting in $1873 \mathrm{CE} / 1251 \mathrm{SH}$, Naser al-Din Shah and many aristocrats were the first members of the royal court to travel to Western Europe and Russia. Taking into account that the plays of Akhundov were published in Persian in 1871 CE/1249 SH, we may completely rule out the idea of European influence on the shabih'gardan director's role. As noted, the annotated shabih'nameh documents we analyzed date mostly from before $1871 \mathrm{CE} / 1249 \mathrm{SH}$.

Indeed, the influence may be the other way round. Many similarities can be found between annotations on shabih'namehs and stage directions seen in the productions in Iran of the first Persian European-style plays, indicating the possibility that shabih'khani may have had a major influence on Western-style playwrighting and theatre production in Iran.

Comparing three different stage directions illustrates this possibility. The first is from the LMDCIP shabih'khani manuscript 20347 (April 1832 CE/Dhu al-Qadah 1247 AH/ Ordibehesht $1211 \mathrm{SH}$ ); the second and third are from early Iranian Western-style stage plays. From manuscript 20347:

After the verse, a woman asks Zaynab for permission and goes towards Kolsum for a pledge [of marriage]. After a conversation with Kolsum, when Kolsum denies the marriage proposal, the woman comes to Zaynab, gets permission, and goes to Sakinah for a pledge. After a conversation with Sakinah, when Sakinah denies the marriage proposal, the woman returns to her husband and speaks [the following verses]. (in Kouchek-zadeh 2011:238; see fig. 9 in SM)

From Mirza Aqa Tabrizi's ca. 1871 CE play, Ashrafkhan: Hakeme Arabestan (اشرف خان؛ حاكم عربستان, Ashrafkhan; Arabian Ruler):

Mr. Karim takes the money and the contract and gives them to Mirza Tarar Khan and says these were sent by Ashraf Khan. At night, Mirza Tarar gives that money to the chieftain. The chieftain signs the contract and assigns his samite to Ashraf Khan. After three days, Ashraf Khan still waits for the contract; he writes a letter to Mirza Tarar and asks for him. (Tabrizi 1977:26)

From another play by Aqa Tabrizi written at about the same time, Hokoomate Zaman Khan-E-Boroojerdi ( حكومت زمان خان بروجردى, The Reign of Zaman Khan-E-Boroojerdi):

Haji Rajab goes to the bath; comes out and enters the room. He puts the key to his cash box in front of Yazdanbakhsh and says [...] (Tabrizi 1977:75)

Aqa Tabrizi (ميرزا آقا تبريزى) (?-1915 CE/1294 SH) wrote the first Persian European-style plays. Most interestingly, Tabrizi wrote both plays quoted above during the construction of Tekyeh Dowlat (Amjad 1999:102). Thus, he was most probably well versed in the conventions of the shabih'nevis and the practice of incorporating stage directions. He was also well aware of his contemporary playwrights, particularly the aforementioned Mirza Fatali Akhundov (Akhundzadeh), but their works differed greatly. They corresponded and their letters reveal their different conceptions of theatre and the performing arts. Akhundov was highly influenced 
by the realistic theatre in Tbilisi, Georgia, while Tabrizi's work bears the marks of a shabih'nevis. We conclude that the Qajar and Naseri era shabih'namehs were developed free from European influence. Their innovations were their own original contributions.

\section{Directorial Annotations in Shabih'khani}

Because shabih'khani has very little in the way of stage sets, relying primarily on stage action, costumes, and props, these are of special interest. For example, in manuscript number 20200, "Place a white fabric on a pillow in a way to show the shadow of a black scorpion. The puppet designer [na'shsaz, نعش ساز] should make the third scorpion bigger" (in Kouchek-zadeh 2011:135). Or for the new majles, Mabshar (مشير, The Day of Judgment), manuscript number 20436: "This number of actors and equipment is good for Tekyeh Dowlat and affluent audiences but should be cut by one third for smaller tekyehs and peasant audiences" (300). In manuscript number 20517, "Signs on each page indicate intervals that can be used or omitted when the majles needs to be shortened" (356).

There are notes on music and sound effects, such as, "Beat the drums, Habib throws in the stone" (20362); "Beat the drums" (20367); "Beat on the naqbareb" "20432); "Israfil blows four times into the trumpet. Start music, open the curtain to heaven" (20436); "Beat on drums for a fight. Beat on drums for mourning" (20513); "Start mournful music" (20436); "Supporting characters sing mournfully" (20206); "Imam sings Chavooshi” (20265); "[Moslem] sings Chavooshi” (20486). Clearly music helped set the scene, created atmosphere, and facilitated changes in rhythm and energy.

In the shabih'nameh of the Naseri era, two innovative technical elements first appeared: lists of characters and lists of props and equipment (see figs. 10 and 11 in SM). These additions to the scripts, which facilitated the productions, were never seen by the public; it is safe to assume that these notes were used by the shabih'gardan during rehearsals. A list of characters can be seen in manuscripts written during Fath-Ali Shah Qajar's reign (see Chodźko 1878; Pelly 1879; and Litten 1929). However, a second list in these collections was seemingly added by Mohammad Taqi and Mohammad Bagher, who were the playwrights of many of the majleses. Although lists of characters can be found in early Persian-language European plays, there are not usually lists of equipment or props (see table 1 in SM).

Mohammad Bagher Mo'in-ol-Boka used stage equipment and techniques similar to those used by a modern-day theatre director. For instance, there is evidence that he designed a crane that lowered the character of the Angel Gabriel from the ceiling of Tekyeh Dowlat onto the stage. Another device was a flaming chariot from hell wheeled around the stage. In Tekyeh Dowlat's detailed financial documents, the crane is referred to as charkb-e-nozool-e-malaek (جֶ) خ نزول ملائك), a pulley to facilitate the descent of angels) and the chariot as charkb-e-asbabe-jahanam (جر خ اسباب جنان), Chariot of Hell). Expenses paid to build the crane were 9 tomans, and to build the chariot it cost 20 tomans and 5 gherans, all paid in full. ${ }^{35}$ The importance of such stage machinery can be assessed by comparing their costs with the wages for the most important actor, the man who played the role of Imam Hussein, known as the Imam'khan (Imam reciter), which was 15 tomans for approximately 10 performances (Bayani 2012:658).

As a manager, Mohammad Bagher pioneered the preparation of posters and brochures for each year's performances at Tekyeh Dowlat (fig. 10). We cannot know exactly when these

34. The nagghareh is a drum played in Persian music. It has a rounded back and a wide head. The naghareh is usually played in pairs.

35. Toman and gheran were the national Persian currency of the time. The gheran was worth one-tenth of a toman. According to Ghahreman Mirza Ein-o-Saltaneh, two horses were worth 80 tomans on 4 Muharram $1306 \mathrm{AH}$ [September $1888 \mathrm{CE}$ ] (1995:175). A four-person carriage was worth 250 tomans on 13 Dhu al-Qadah $1306 \mathrm{AH}$ [July 1889 CE] (213). 
posters were first printed, but the oldest extant poster was designed for the majles Vorood Be Karbala (ورود به كربلا, Entering Karbala), performed on 6 December 1880 CE/3 Muharram 1298 AH/16 Azar 1259 SH, several years before the first European-style theatre was performed publicly in Iran.

Among 16 existing Tekyeh Dowlat posters, three date to $1880 \mathrm{CE}$, nine to 1881, and four to 1884 . These posters make clear that even though all performances were at Tekyeh Dowlat during the first 10 days of the month of Muharram, the repertoire changed every year and Mohammad Bagher planned, publicized, and directed a different set of shabih'namehs each year. The Tekyeh Dowlat posters he prepared are not only the first form of advertisement for any Iranian theatre, they are also the first for any artistic work in Iran.

\section{Early Signs of Dramaturgy in Shabih'namehs}

The primary duties of Mohammad Bagher Mo'in-ol-Boka were reading, reviewing, and editing old and new shabih'namehs, tasks primarily assigned to a dramaturg in contemporary theatre. Since Mohammad Bagher was a shabih'nevis, shabih'gardan, and head of royal shabih'khani of Tehran, he wrote critical annotations and suggestions on manuscripts and gave other shabih'nevises and sometimes shabih'gardans the chance to edit scripts and change performances. His remarks were often candid and brief: "Old, this is useless" (20474); or "This chant is new; it should become a fard [included in a side]" (20417); or "It is reviewed; it should become a fard" (20456). According to the latter annotation, "this fard is confirmed and can be used for shabih'khani." At times he provided a more detailed analysis of the text. For instance, in Dafn Kardan Shohada va Fabal va Rezvan (دفن كردن شها و جبل و رضوان, Burying the Jabal, Rezavan, and the Martyrs; 20213), he suggests:

One dialogue suffices between Shimr and Ibn Sa'ad. No need for a dialogue between Imam and Darda'il. Cut giving water to Hurr, brother, boy, and slave. Start from [the part where] water is handed to Ali Akbar until the end. No need for Gabriel to sing after each martyr drinks water. This is to shorten. (see figs. 12 and 13 in SM)

Along the same line are his annotations on manuscript 20411:

Reviewed. A brief passage must be added in the sixth majles. However, eliminating this passage will not be harmful. No need to add or erase. Some verses are needed for a dialogue between brother and sister. Some are also needed for a dialogue between mother and daughter in order to persuade the father not to kill Abdullah. Hatef's chant in the name of Hussein is good in every way. (see figs. 14 and 15 in SM)

These examples show Mohammad Bagher's abilities as a dramaturg, eliminating superfluous parts and adding dramatically necessary elements. He searches for ways to establish the appropriate pacing and dynamic between characters. He points out the flaws in the plots of the shabih'namehs and provides suggestions on how to adjust them. In some texts, he recommends taking one passage and using it in another moment in the performance. The following is a common note repeated in a number of texts:

After the messenger approaches the Imam, he starts reciting a quote from Fala-Ol-Oyoon (جلاء العيون, Washing the Eyes), about Loghman ibn Bashir on the pulpit, praising the Prophet. After this, Abdullah Moslem sends a letter to Yazid. As this is lengthy and irrelevant, I removed Loghman from the pulpit. [...] Since there is no evidence of the Imam being present here, according to the hadith [حديث], it is enough, and he shall be martyred here. However, as the dialogue with Imam is in the present tense, it can be used. 

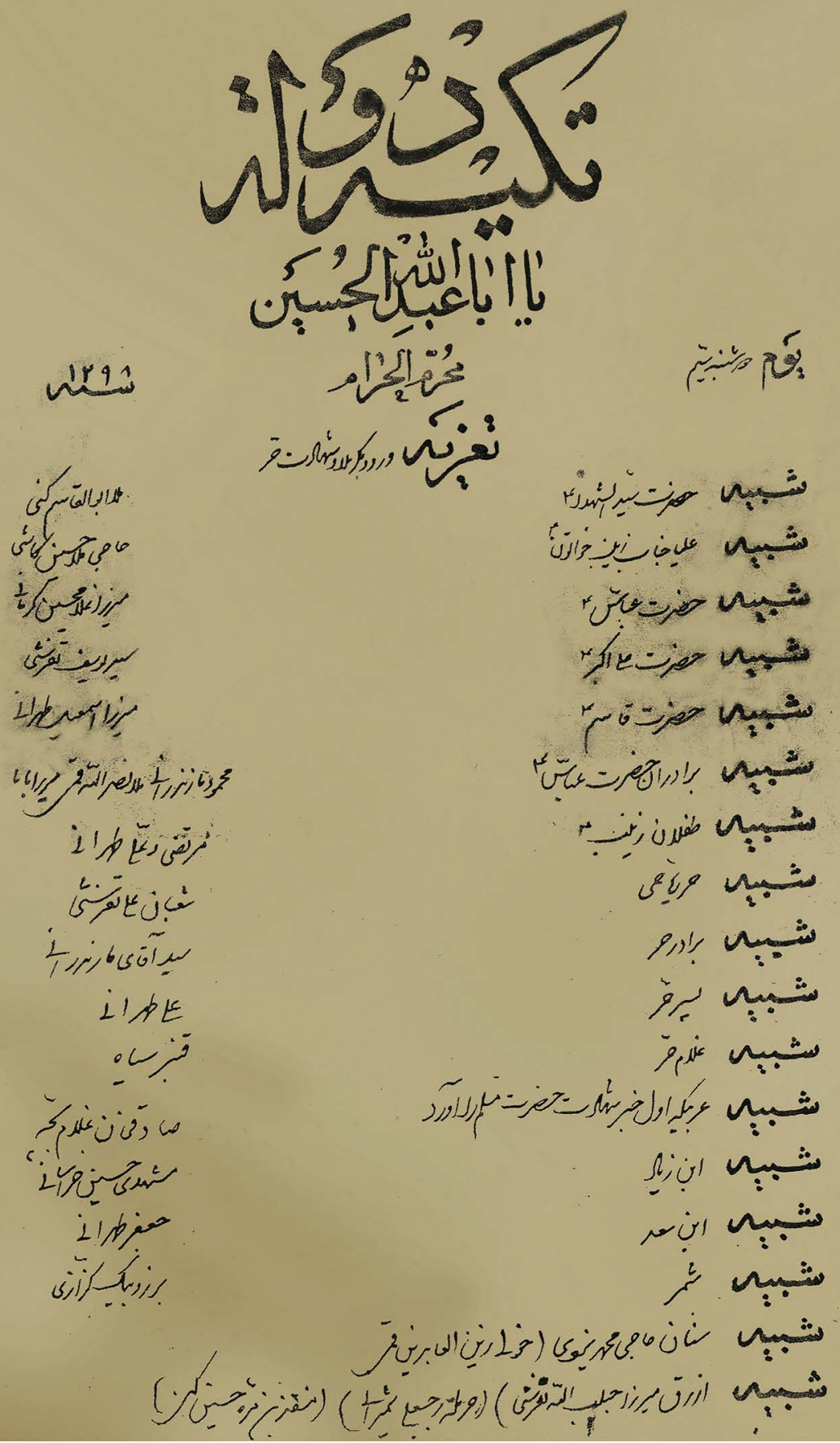

Figure 10. This sample of Tekyeh Dowlat's posters is the oldest existing poster of shabih'khani and published here for the first time. (Photo courtesy of the Institute for Iranian Contemporary Historical Studies) 
The Imam can recite, if he desires, otherwise it is not necessary to adhere to the hadith. (20307; see fig. 16 in SM) ${ }^{36}$

Such a novel, nearly revolutionary, prioritizing of theatrical needs over religious orthodoxy is a remarkable characteristic of the writings of Mohammad Bagher Mo'in-ol-Boka. His annotation on Ta'va'lode Ha'zrat-e Isa (تولد حضرت عبسا, The Birth of Jesus) points to the unique conventions of shabih'khani:

After Gabriel looking through Jesus's two fingers at Jesus's invitation, [you can] add any passage you want. Then, read the second passage or all (of them) and then move to the next. (20155)

Authors of shabih'namehs placed no restrictions on text alterations and/or edits by shabih'gardans. Certain passages, called goosheh (كوشه), ${ }^{37}$ may be added to the main storyline, becoming independent episodes occurring anywhere in a majles. In another document, one shabih'nevis writes, "Read a new goosheh [...] in the funeral [scene] for the Prophet" (20458), clearly leaving the shabih'gardan in charge of selecting the goosheh and determining its placement in the performance. For example, "additional dialogues between the characters, Zaynab, Imam Ibad, and Sakinah can be used in the majles Vafate Zaynab (وفات زينب, Zaynab’s Passing), Asbab Pas Dadan (داسباب بس دادن, Returning Items), and Deyre Solomon (دير سليمان, Solomon's Monastery)” (20500), indicating the use of gooshehs from different texts, borrowing from one another.

Every shabih'khani performance could be modified in order to comply with the needs of the organizer, audience, and actors as well as to take into account the resources available. Performances could be extended or shortened depending on circumstances, sometimes during the course of the performance itself. As both the author and director, Mohammad Bagher was conscious of the logistics of a performance and built notes regarding production into the majleses he wrote and/or directed. "Notations have been made for episodes to be used, which can be omitted if the majles is to be shortened" (20517). When text was added, it was necessary for shabih'nevises to refer to the sources of the borrowed verses, and also to document their own shabih'namehs. Some titles of shabih'namehs in the LMDCIP collection include Mohammad Bagher's notes of his sources. For example, from different manuscripts: "Majles Aroosiy-e Fattemeh (عروسى فاطمه, Fatimah's Wedding) is adapted from falal-Ol-Oyoon, a book written by the late Allamah Majlesi" (20373; see fig. 17 in SM); "Mojezeye Imam Hassan dar Chin (معجزه امام حسن در حِين) The Miracle of Imam Hassan in China) is a quote from Mola Aqa

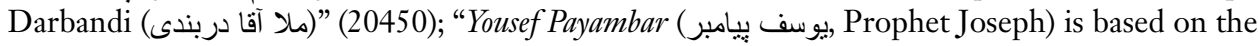

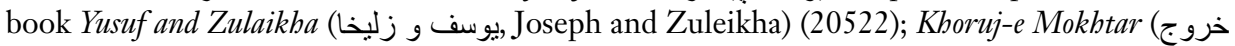
مختار, Mokhtar's Exit), accepted by all ulama (علمار (ع) and adapted by myself [Mohammad Bagher] from Fala-Ol-Oyoon written by Allameh Majlesi, original hadith is correct and without errors" (20193; see table 2 in SM).

There is even an instance of Mohammad Bagher criticizing his own writing. On top of the first page of his majles Shast Bastan Div, he notes: “This has poor quality. Mirza Ba'ba'y-e Nayeb’s (ميرزا باباى نايب) text is better [than mine]” (20242). This simple note points to Mohammad Bagher's pursuit of a better play, modestly dismissing his own creation.

36. Hadith in Islam is the recorded words, actions, and silent approvals, traditionally attributed to the Prophet Muhammad and Shi'a Imams.

37. Goosheh is also a term referring to distinct melodic motifs in the system of Persian classical music. Since the sympathetic characters in shabih'khani chant/recite using Persian musical modes, the parallelism between the texts, the dramatic episodes, and the musical elements in which they are expressed is an important feature in the structure of the overall performance. As has been noted, Mohammad Bagher frequently suggested musical modes and motifs for performances under his direction.

38. In Islam, the ulama are the guardians, transmitters, and interpreters of religious knowledge, of Islamic doctrine, and law. 


\section{Theatre Directing in Europe and the Work of the Shabih'gardan}

According to histories of theatre directing in Europe, certain tasks of modern-day directors initially were performed by playwrights, playwright-managers, and actor-managers. However, in the last quarter of the 19th century the modern director emerged. The history is well-known, from Ludwig Chronegk (1837-1891), the artistic director of the Meiningen Ensemble created by Georg II, Duke of Saxe-Meiningen (1826-1914); on to André Antoine (1858-1943); Edward Gordon Craig (1872-1966); Konstantin Stanislavsky (1863-1938), and the multitude of directors who followed. The Meiningen Ensemble toured Europe from 1874 to 1890 . Under the Duke's watchful eye and Chronegk's directing, the ensemble became famous for choreographed crowd scenes, historically accurate sets, costumes, props, and ensemble acting, rejecting the star system (see table 3 in SM).

Aubin's eyewitness report and the materials we have analyzed from the LMDCIP, the Malek National Museum and Library of Iran, and private collections clearly show that Mohammad Bagher Mo'in-ol-Boka did the work of a director by European standards several years prior to the Meiningen Ensemble. The evolution of the director in Iran started with Mirza Mohammad Taqi Ta'ziyehgardan and was revolutionized by Mohammad Bagher.

The first American Minister to Persia, Samuel Greene Wheeler Benjamin, saw performances towards the end of Tekyeh Dowlat's first decade. He wrote:

The entire performance was directed by a prompter, who walked unconcernedly on the stage, and gave hints to the players or placed the younger actors in their position. At the proper moment also, by a motion of the hand, he gave orders for the music to strike up or stop. But it was curious how soon I ceased to notice him at all; indeed, after a short time I was scarcely aware of his presence. (1887:392)

At about the same time Abdullah Mostofi wrote:

Mo'in-ol-Boka carries all actors' manuscripts, a stack of well-organized paper in his waist shawl [figs. 4, 6, 7, 8]. This was in case any of the actors forgot theirs, so he had a spare. He manages his work very well. All his commands are thoroughly obeyed by all 100 actors and musicians [...]. He gestures with his cane towards the actors and the musicians to give his instructions to start or stop, in a dignified manner. Even if among the audience, someone sitting in a private balcony or around the stage, makes a sound, Mo'in-olBoka would cast a solemn look at them for them to stay quiet. ([1947] 1981:297-98)

British missionary Clara Rice, living in Iran approximately between $1910 \mathrm{CE} / 1289 \mathrm{SH}$ and 1912 CE/1291 SH, describes how "some of the actors bawl, others cannot be heard; the prompter is always in evidence" (1923:234). According to her notes, it becomes clear that the stage-director/prompter (ostad) was constantly on the stage in the middle of the scene with a piece of paper in hand. He would carry the roles of all actors, directing and assigning them to their proper places; he "never quitted the stage, and gave frequent explanations of whatever appeared unclear or ambiguous" (Mounsey 1872:314). ${ }^{39}$

Referring to Mirza Mohammad Taqi, Mostofi writes, "anywhere he found a talented person, Mirza would follow him, and by force or promise, prepared that person for shabih'khani" ([1947] 1981:290). This method was also practiced by Mohammad Bagher Mo'in-ol-Boka. Posters from Tekyeh Dowlat confirm this (fig. 10; fig. 18 in SM). Actors' names are followed

39. Regarding Persian Le mécénat (directors) and theatre see also Chodźko (1878:174); Calmard (1979:98); Ahmed Bey (1892:533); Rice (1923:234). 
by their city of origin in these posters, such as Kani, Kashani, Kermani, Tafreshi, Mazandarani, Tehrani, Khorasani, Yazdi, Shemirani, Mahalati, etc. ${ }^{40}$

Mohammad Bagher selected the best performers for four-month contracts. Rehearsals lasted three months. The last month, the month of Muharram, was dedicated to the performances. The troupe toured to different tekyehs in the area with shabih'khanis starting in the early morning and continuing till late at night with up to seven performances a day.

Even more than his European counterparts, Mohammad Bagher controlled the productions for which he was both director and dramaturg. He also monitored other shabih'khani troupes in Tehran, occasionally loaning them his actors. He selected, edited, and wrote plays; he designed posters and supervised the repertory; he adapted literary texts for the theatre; he analyzed and compared texts with related religious stories; he introduced innovations in shabih'khani verse and music; he supervised performers, including their movements, gestures, and the correct ways to speak the parts; he added physical features to mythical characters, simplifying them for audiences; he searched for and recruited the best actors from different cities; he employed professional musicians to teach the actors different Persian musical dastgāhs (دستخاه) or modes; he led long hours of music rehearsals and directed the musicians during performances; he designed costumes, props, stage machinery, puppets, and masks; he employed animal trainers and choreographed horses, camels, elephants, lions, pigeons, etc.

Mohammad Bagher was onstage throughout the performance leading his actors and musicians in real time. He oversaw actors' entrances and exits, carried and placed props on the stage and even acted as the leader and reference point for audience participation and collective mourning, which included chest-beating, self-flagellation, and chanting. His presence on the stage did not interfere or distract. On the contrary, it became one of ta'ziyeh's conventions. ${ }^{41}$ The result were performances that shunned realism, that focused on the theatricality of shabih'khani. Under Mohammad Bagher Mo'in-ol-Boka's leadership, shabih'khani was transformed from a historical reenactment into a symbolic, creative theatre genre. He emphasized theatricality rather than religious orthodoxy, with themes such as speculations on the afterlife, spiritual redemption, and the supernatural (see fig. 19 in SM).

\section{The Formation of Directing in Shabih'khani}

Before Mohammad Taqi and Mohammad Bagher the shabih'gardan was similar to the Western actor-manager. Both, but Mohammad Bagher especially, transformed the shabih'gardan into a professional director. He was recognized in Iran for his official work as director of Tekyeh Dowlat. The first directors in Europe and in Iran had no knowledge of each other, yet what they did and when they did it coincide remarkably, offering us a new intercultural perspective on the emergence of the modern theatre director.

Theatre historians have paid little or no attention to the development of directing and dramaturgy outside Europe. The newly rediscovered shabih'khani manuscripts from the Qajar era in Iran show that directing and dramaturgy were practiced in traditional Iranian theatre starting in the late 18th century and further developed in the 19th century.

40. For example, Abolqasem Kani, mentioned on the poster and performing the role of Imam Hussein, was born in Kan, an old village located northwest of Tehran; Kani is a postfix for those from Kan. Placing an "i" after a place name indicates where people are from: Kashani is placed after the name of someone from Kashan.

41. In the 20th century, the Polish director-auteur Tadeusz Kantor (1915-1990) also was onstage throughout performances of his Cricot 2 Theatre. And of course, orchestra conductors are onstage conducting. Kantor's presence had a dramatic effect: he sometimes directed the actors or looked at the audience. Mohammad Bagher was on the stage solely to prepare and arrange props and actors. His presence wasn't part of the drama as was Kantor's. 
Sophisticated directorial techniques for shabih'khani in late 18th- and 19th-century Iran responded to the need to create highly effective performances for remarkably large audiences. If all forms of theatre are reliant on their audiences, it will not be surprising that, in the Naseri era of the Qajar Empire, shabih'khani, with over 20,000 spectators at each performance in Tehran's Tekyeh Dowlat and large audiences in other venues (Beyzai 1965:129; Etemad al-Saltanah 1889:58), demanded high technical and theatrical competence (see figs. 11 and 12). The boundless appetite of Iranian audiences for this kind of theatrical presentation resulted in a wealth of shabih'khani performances throughout Iran, driving ever more elaborate technical, theatrical, directorial, and dramaturgical innovations.

In an increasingly religious era, Mohammad Bagher Mo'in-ol-Boka's frequent rewriting and editing of historical religious tales not only failed to raise opposition from the clergy and the public but enjoyed widespread acclaim and popularity. His innovations in stage direction, movement, and theatrical reform in the Naseri era shabih'nameh is a clear indication of his theatrical knowledge. While his predecessors wrote verses that were often unperformable, Mohammad Bagher resurrected and edited texts that he deemed suitable for large audiences, recreating them as splendid works of theatre. The technical and theatrical duties of shabih'nevises and shabih'gardans and their development into a professional theatrical practice, as revealed in these newly discovered manuscripts, tailored shabih'khani to the society it served and the stories it told.

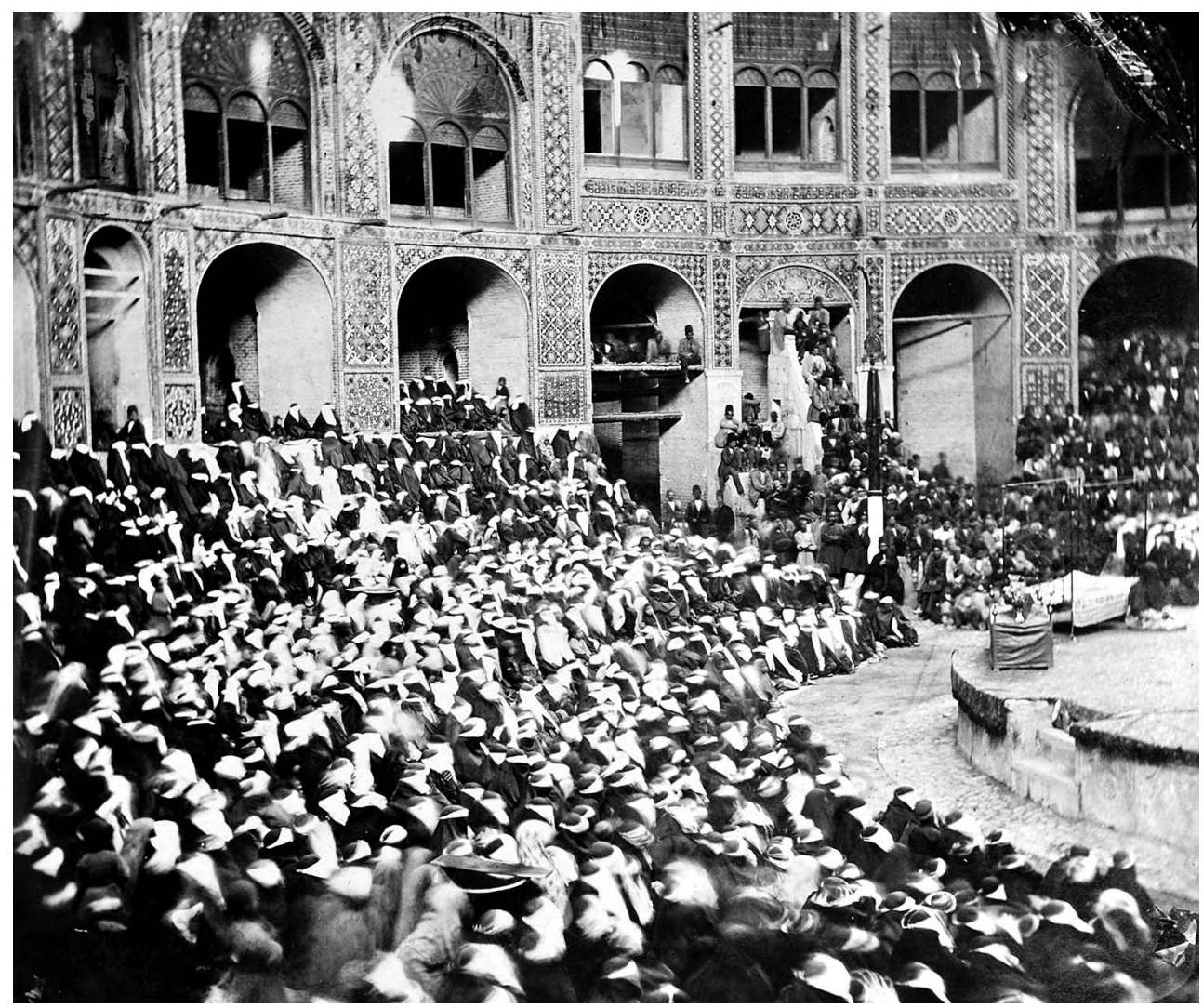

Figure 11. Women's auditorium at Tekyeh Dowlat. (Photo courtesy of Golestan Palace, 391st Album) 


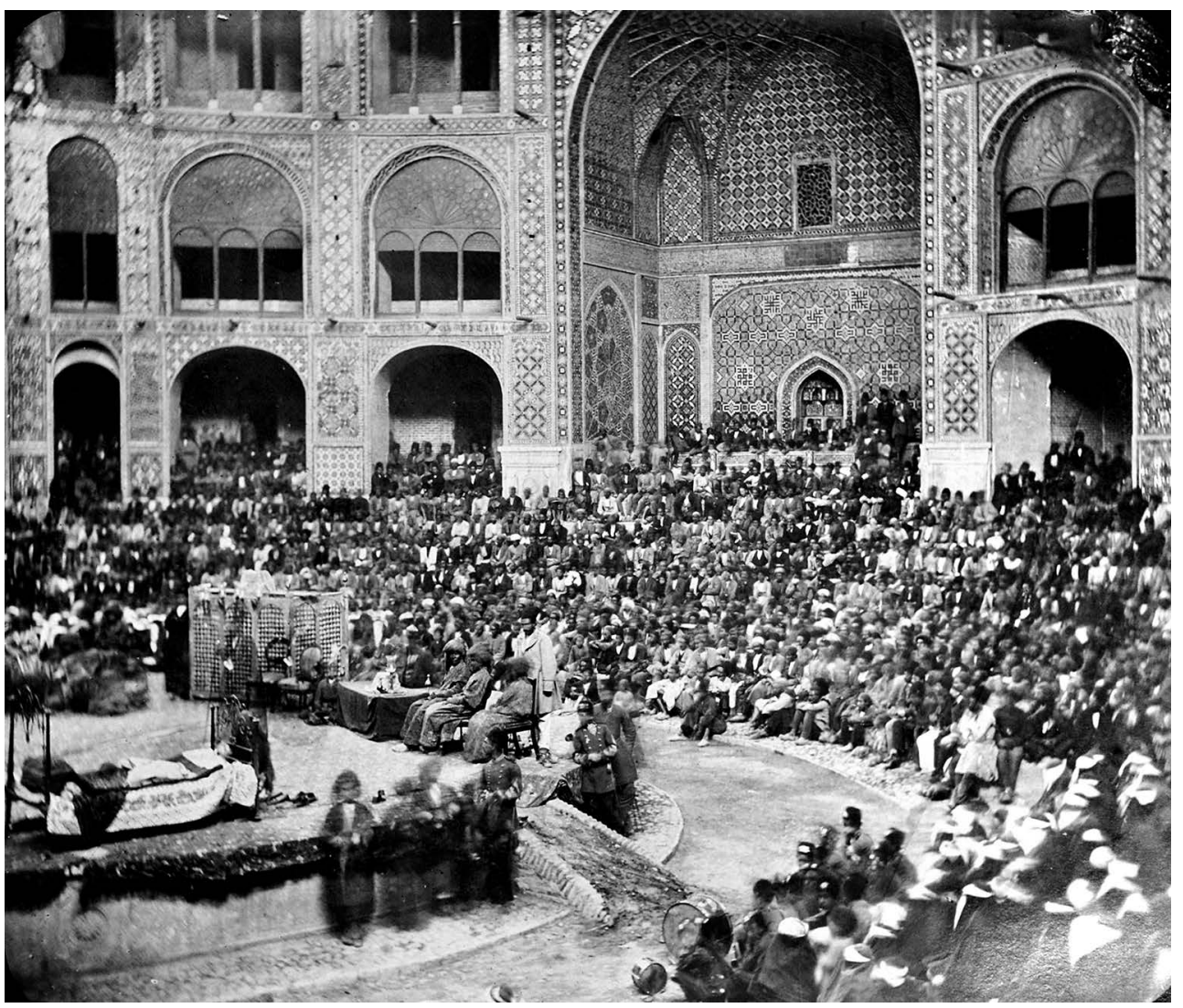

Figure 12: Men's auditorium at Tekyeh Dowlat. (Photo courtesy of Golestan Palace, 391st Album)

\section{References}

Afshar, Iraj. 1966. "Old-Printed Books in Iran.” Art \& People 49:26-33.

Aghaie, Kamran Scot. 2004. The Martyrs of Karbala: Shii Symbols and Rituals in Modern Iran. Seattle: University of Washington Press.

Ahmed Bey, Ağaoğlu. 1892. "La Société Persane: le théâtre et ses fêtes." La Nouvelle Revue 77:537-38.

Ale-Mohammed, Reza. 2001. "An Iranian Passion Play: 'Taziyeh' in History and Performance.” New Theatre Quarterly 17, 1:54-66. doi:10.1017/S0266464X00014329.

Amanat, Abbas. 1997. Pivot of the Universe: Nasir Al-Din Shab Qajar and the Iranian Monarchy, 1831-1896. Berkeley: University of California Press.

Amjad, Hamid. 1999. Thirteenth Century Theater. Vol. 1. Tehran: Nila Pub.

Anvar, Iraj. 1990. “A Study of Peripheral Ta'ziyeh in Iran.” PhD diss., New York University.

Anvar, Iraj. 2005. "Peripheral Ta'ziyeh: The Transformation of Ta'ziyeh from Muharram Mourning Ritual to Secular and Comical Theatre." TDR 49, 4 (T188):61-67. doi.org/10.1162/105420405774762970.

Arnold, Matthew. 1871. “A Persian Passion Play.” The Cornhill Magazine 24, 144:668-87.

Aubin, Eugène. 1908. La Perse d'aujourd'bui-Iran, Mésopotamie. Paris: A. Colin.

Baktash, Mayel. 1969. “Tahavol Moghe Ejtemae’i va Jaha'te Arzy'abi Taziyeh (9).” Bamshad, January.

Baktash, Mayel. 1979. “Ta'ziyeh and Its Philosophy.” In Ta'ziyeh: Ritual and Drama in Iran, ed. Peter J. Chelkowski, 95-120. New York University Studies in Near Eastern Civilization, no. 7. New York: New York University Press. 
Bayani, Bahman. 2012. Keta'bche fa'me' va Kha'rje Kol Ha'za't Sena't A'ya't Ye'il Ma'ma'leke Ma'broose' Mota'beghe Sene 1304 Hijri [Accounting Book of 1304 Lunar Year]. Tehran: Parliament Library.

Beeman, William O. 1979. “Cultural Dimensions of Performance Conventions in Iranian Ta'ziyeh.” In Ta'ziyeh: Ritual and Drama in Iran, ed. Peter J. Chelkowski, 24-31. New York University Studies in Near Eastern Civilization, no. 7. New York: New York University Press.

Beeman, William O. 1981a. "A Full Arena: The Development and Meaning of Popular Performance Traditions in Iran: The Dialectics of Continuity and Change." In Modern Iran: The Dialectics of Continuity and Change, ed. Michael Bonine and Nikki R. Keddie, 361-82. Albany: State University of New York Press.

Beeman, William O. 1981b. "Why Do They Laugh? An Interactional Approach to Humor in Traditional Iranian Improvisatory Theater: Performance and Its Effects." The fournal of American Folklore 94, 374:506-26. doi.org/10.2307/540503.

Beeman, William O. 1982. Culture, Performance and Communication in Iran. Tokyo: Institute for the Study of Languages and Cultures of Asia \& Africa.

Beeman, William O. 2003. "Performative Symbols and Their Relative Non-Arbitrariness: Representing Women in Iranian Traditional Theater.” Semiotica 145 (January):1-19.

Beeman, William O. 2007. “Classical Persian Music, Islam and Ta'ziyeh.” In Muraqqa'e Sharqi : Studies in Honor of Peter Chelkowski, ed. Soussie Rastegar and Anna Vanzan, 43-56. San Marino: AIEP Editore.

Beeman, William O. 2011. Iranian Performance Traditions. Bibliotheca Iranica: Performing Arts Series, no. 9. Costa Mesa, CA: Mazda Publishers, Inc.

Beeman, William O. 2017. “Martyrdom, Shi’a Islam, Ta'ziya: Political Symbolism in Shi’a Islam.” In Martyrdom and Sacrifice in Islam: Theological, Political and Social Contexts, ed. Meir Hatina and Meir Litvak, 224-43. London: IB Tauris.

Beeman, William O., and Mohammad B. Ghaffari. 2005. "Acting Styles and Actor Training in Ta'ziyeh." TDR 49, 4 (T188):48-60. doi.org/10.1162/105420405774762943.

Benjamin, Samuel Greene Wheeler. 1887. Persia and the Persians. London: J. Murray.

Beyzai, Bahram. 1962. "Shimr and Abbas." Arash fournal 5:26-39.

Beyzai, Bahram. 1965. نمايش در ايران [Namayesh Dar Iran, Theatre in Iran]. Tehran: Chap-e Kavian.

Boozari, Ebrahim. 1978. Taziyeh Dar Iran Va Do Majles An. Tehran: Intishārāt-i Vizārat-i Farhang va Hunar.

Calmard, Jean. 1974. "Le mécénat des représentations de ta'ziye." Le Monde iranien et l'Islam 2, 4:73-126, $133-62$.

Calmard, Jean. 1979. “Le Patronage Des Ta'ziyeh: Éléments Pour Une Étude Globale.” In Ta'ziyeb: Ritual and Drama in Iran, ed. Peter J. Chelkowski, 73-126. New York University Studies in Near Eastern Civilization, no. 7. New York: New York University Press.

Cerulli, Enrico. 1954. “Una Nova Collezione Di Manoscritti Persiani Della Biblioteca Vaticana.” Rendiconti Dell'Accademia Nazionale Dei Lincei 8, 9:507-15.

Cerulli, Enrico. 1971a. "Le theatre persan.” In L'Islam di ieri e di oggi, 435-46. Rome: Istituto per l'Oriente.

Cerulli, Enrico. 1971b. "Le theatre persan et ses origines." In L'Islam di ieri e di oggi, 429-34. Rome: Istituto per l'Oriente.

Cerulli, Enrico. 1971c. L'Islam di ieri e di oggi. Rome: Istituto per l'Oriente.

Chelkowski, Peter J. 1977. “Ta'ziyeh: Indigenous Avant-Garde Theatre of Iran.” Performing Arts fournal 2, 1:31-40. doi.org/10.2307/3244963.

Chelkowski, Peter J., ed. 1979. Ta'ziyeh: Ritual and Drama in Iran. New York University Studies in Near Eastern Civilization, no. 7. New York: New York University Press.

Chelkowski, Peter J. 1985. “Shia Muslim Processional Performances.” TDR 29, 3 (T107):18-30. doi.org/10.2307/1145650.

Chelkowski, Peter J. 2005. “Time Out of Memory: Ta'ziyeh, the Total Drama.” TDR 49, 4 (T188):15-27. doi.org/10.1162/105420405774763050. 
Chelkowski, Peter J., and Mohammad Ghaffari. 2005. “Mohammad B. Ghaffari: Ta'ziyeh Director.” TDR 49, 4 (T188):113-29. doi.org/10.1162/105420405774762934.

Chodźko, Alexander. 1878. Théatre persan; choix de téaziés ou drames. Paris: E. Leroux.

Cook, David. 2007. Martyrdom in Islam. Cambridge: Cambridge University Press.

Daryaee, Touraj, ed. 2012. The Oxford Handbook of Iranian History. Oxford: Oxford University Press.

Ein-o-Saltaneh, Ghahreman Mirza. 1995. Roozna'mehe Khaterat, ed. Iraj Afshar. Vol. 1. Tehran: Asatir.

Ekhtiar, Maryam. 2001. "Nasir al-Din Shah and the Dar al-Funun: The Evolution of an Institution." Iranian Studies 34, 1/4:153-63. www.jstor.org/stable/4311427.

Ekhtiar, Maryam, and Marika Sardar. 2004. "Nineteenth-Century Iran: Art and the Advent of Modernity." In Heilbrunn Timeline of Art History. New York: The Metropolitan Museum of Art. www.metmuseum. org/toah/hd/irmd/hd_irmd.htm.

Etemad al-Saltanah, Mohammad Hassan Khan. 1887. "Tekyeh Mobarakey Dowlati [Holy Tekyeh Dowlat]." Sharaf Montbly, Muharram [October].

Etemad al-Saltanah, Mohammad Hassan Khan. 1889. Almaa'ser-o val A'sa'r. Tehran: Da'r-ol-Ta'ba'yeh' Kha'seye' Dowlati.

Farhat, Hormoz. 1990. The Dastgāa Concept in Persian Music. Cambridge: Cambridge University Press.

Floor, W.M. 1979. “The Bankers (Șarrāf) in Qājār Iran.” Zeitschrift Der Deutschen Morgenländischen Gesellschaft 129, 2:263-81. www.jstor.org/stable/43376283.

Floor, Willem M. 2005. The History of Theater in Iran. Washington, DC: Mage Publishers.

Francklin, William. 1790. Observations Made on a Tour from Bengal to Persia, in the Years 1786-7. 2nd ed. London: Printed for T. Cadell.

Gaffary, Farrokh. 1984. "Evolution of Rituals and Theater in Iran.” Iranian Studies 17, 4:361-89. doi.org/10.1080/00210868408701638.

Ghaffari, Mohammad. 1988. "The Director Speaks.” In Ta'ziyeb: Ritual and Popular Beliefs in Iran: Essays Prepared for a Drama Festival and Conference Held at Trinity College and Hartford Seminary, April 30May 2, 1988, ed. Milla Cozart Riggio. Hartford, CT: Trinity College.

Gobineau, Joseph Arthur comte de. 1866a. "Autres Compositions Theatrales.” In Les religions et les philosophies dans l'Asie centrale. 2nd ed., 439-59. Paris: Didier \& Cie.

Gobineau, Joseph Arthur comte de. 1866b. "Les Noces de Kassem.” In Les religions et les philosophies dans l'Asie centrale. 2nd ed., 404-37. Paris: Didier \& Cie.

Gobineau, Joseph Arthur comte de. 1866c. Les religions et les philosophies dans l'Asie centrale. 2nd ed. Paris: Didier \& Cie.

Gobineau, Joseph Arthur comte de. 1866d. "Les Tekyehs ou Theatres.” In Les religions et les philosophies dans l'Asie centrale. 2nd ed., 381-403. Paris: Didier \& Cie.

Homayouni, Sadeq. 1971. Ta'zia Wa Ta'ziak $\underline{k}^{v} \bar{a} n i$ [Ta'ziyeh and Ta'ziyeh Performance]. Tehran: Entešārāt-e jašn-e honar.

Homayouni, Sadeq. 1979. “An Analysis of the Ta'ziyeh of Qasem.” In Ta'ziyeb: Ritual and Drama in Iran, ed. Peter J. Chelkowski, 12-23. New York University Studies in Near Eastern Civilization, no. 7. New York: New York University Press.

Ibn Al-Athir, Ali. 1972. The Complete History. Trans. Abbas Khalili. Vol. 15. Tehran: Sa'ha'mi Cha'p va Entesha'ra't-e Iran.

Ibn Kathir, Abu'l-Fedā Esmāil. 1988. Al-Bidayah Wan-Nihayah. Ed. Ali Shiri. 1st ed., vol. 11. Beirut: Da'r Eh'ya' al-Tara'th al-Arabi.

Jaffri, Sayyed Hussain Ali. 1979. "An Analysis of the Ta'ziyeh Muharram Ceremonies in India.” In Ta'ziyeb: Ritual and Drama in Iran, ed. Peter J. Chelkowski, 222-27. New York University Studies in Near Eastern Civilization, no. 7. New York: New York University Press.

Javaherkalam, Ali. 1965. "Several Audible Events about Ta'zieh in Iran.” Etelaat-E-Mahaneh, 90. 
Kouchek-zadeh, Reza. 2011. Descriptive Catalogue of Qajar Period's Texts of Passion Plays. Tehran: Majles.

Kouchek-zadeh, Reza. 2013. Descriptive Catalogue of Maleck Texts of Passion Plays. Tehran: Maleck.

Krymsky, Ahatanhel. 1925. Перський театр, звідки він узявсь $і$ як розвивавсь [The Persian Theatre: Its Origin and Development]. Kiev (Kyiv): 3 друкарні Української Академії Наук [Ukrainian Academy of Sciences].

Lassy, Ivar. 1916. The Muharram Mysteries among the Azerbeijan Turks of Caucasia: An Academical Dissertation. Helsingfors: Lilius \& Hertzburg.

Litten, Wilhelm. 1929. Das Drama in Persien. Berlin: W. de Gruyter \& Company.

Malik'pūr, Jamshīd. 2004. The Islamic Drama. London: Frank Cass.

Mervin, Sabrina. 2007. "Le théâtre chiite au Liban, entre rituel et spectacle." In Itinéraires esthétiques et scènes culturelles au Proche-Orient, ed. Nicolas Puig and Franck Mermier, 57-75. Beyrouth: Presses de l'Ifpo.

Moayer-ol-Mama'lek, Doostali Khan. 1983. Yadashthayi Az Zendebie Khosoosie Naser al-Din Shah. 1st ed. Tehran: Tarikhe Iran.

Mokhtari, Eskandar. 2018. Architecture of Tekyeh Dowlat. Tehran: Tehran Beautification Organization Press.

Mostofi, Abdullah. (1947) 1981. Sharbe' Zendega'ni Man [Description of My Life]. 2nd ed., vol. 1. Tehran: Zavar.

Mounsey, Augustus Henry. 1872. A Journey Through the Caucasus and the Interior of Persia. London: Smith, Elder \& Company.

Niebuhr, Carsten. 1778. Reisebeschreibung nach Arabien und andern umliegenden Ländern. Kopenhagen: Möller.

Pelly, Sir Lewis. 1879. The Miracle Play of Hasan and Hussein. 2 vols. London: W.H. Allen.

Qajar, Naser al-Din Shah. 1999. The Diary (1300-1303). Ed. Parviz Badiei. Vol. 1. Tehran: National Library of Iran.

Rahimi, Babak. 2013. “The Qajar Theater State: The Takiy-eh Dawlat of Tehran.” In Performing the Iranian State: Visual Culture and Representations of Iranian Identity, ed. Staci Gem Scheiwiller, 55-71. London: Anthem Press.

Redden, Nigel. 2005. "Presenting Ta'ziyeh at Lincoln Center.” TDR 49, 4 (T188):124-25. doi.org/10.1162 /dram.2005.49.4.124.

Rice, Clara Colliver Hammond. 1923. Persian Women and Their Ways. Philadelphia: J.B. Lippincott.

Riggio, Milla C. 1994. “Ta'ziyeh in Exile: Transformations in a Persian Tradition.” Comparative Drama 28, $1: 115-40$.

Riggio, Milla Cozart. 2005. "Moses and the Wandering Dervish: Ta'ziyeh at Trinity College." TDR 49, 4 (T188):100-12. doi.org/10.1162/105420405774762916.

Rossi, Ettore, and Alessio Bombaci. 1961. Elenco dei drammi religiosi Persiani: fondo Mss. vaticani Cerulli. Citta del Vaticano: Biblioteca apostolica vaticana.

Salmon, Thomas, and Matthias van Goch. 1739. Die Heutige Historie Und Geographie. Altona: Im Verlag der Gebrüder Korte.

Sayyad, Parviz. 1971. Courage Hurr. Tehran: Shiraz Arts Festival Publisher.

Sepehr, Abdolhossain. 2007. Mer'at-Ol-Vaghaye Mozafari. Tehran: Mirasmaktoob.

Shahidi, Enayatullah. 1979. "Literary and Musical Developments in the Ta'ziyeh.” In Ta'ziyeb: Ritual and Drama in Iran, ed. Peter J. Chelkowski, 222-27. New York University Studies in Near Eastern Civilization, no. 7. New York: New York University Press.

Shahidi, Enayatullah. 1999. “Tekyeh Dowlat va Baresihaye Naghes va Nadorost darbareye An” [Tekyeg Dowlat and the incomplete and incorrect studies about it]. Faslnameb Theatre 18, 2:37-101.

Shahidi, Enayatullah, and Ali Bulookbashi. 2001. Pazhubeshi Dar Ta'ziyeh va Ta'ziyeh Khani Az Aghaz Ta Payan-e Dowreh-Ye Qajar Dar Tebran [Research on Ta'ziyeh and Ta'ziyeh Khani from the Beginning to the End of the Qajar Era in Tehran]. Tehran: Cultural Research Bureau and Iranian National Commission for UNESCO. 
Shahvar, Soli. 2006. "Communications, Qajar Irredentism, and the Strategies of British India: The Makran Coast Telegraph and British Policy of Containing Persia in the East (Baluchistan): Part I." Iranian Studies 39, 3:329-51. doi.org/10.1080/00210860600808151.

Stewart, Dona J. 2009. The Middle East Today: Political, Geographical and Cultural Perspectives. London: Routledge.

Tabrizi, Mirza Aqa. 1977. 5 Nama'yeshna'meb'. Tehran: Roshangaran.

Tajbakhsh, Ahmad. 1998. Tarikh-e Tamadon va Farhang Iran, Doreb-e Qajar. Shiraz: Navid-e Shiraz.

Thaiss, Gustav Edward. 1973. "Religious Symbolism and Social Change: The Drama of Hussein.” PhD diss., Washington University in St. Louis, MO.

Ward, Steven R. (2009) 2014. Immortal: A Military History of Iran and Its Armed Forces. Washington, DC: Georgetown University Press.

Yarshater, Ehsan. 1979. “Ta'ziyeh and Pre-Islamic Mourning Rites in Iran.” In Ta'ziyeb: Ritual and Drama in Iran, ed. Peter J. Chelkowski, 88-94. New York University Studies in Near Eastern Civilization, no. 7. New York: New York University Press.

Yarshater, Ehsan. 2001. "The Qajar Era in the Mirror of Time.” Iranian Studies 34, 1/4:187-94. doi.org/10 $.1080 / 00210860108702005$.

Yeganeh, Farah. 2010. "Ta'ziyeh as Theatrical Event.” In Koski, Pirkko, and Melissa Sihra, eds. The Local Meets the Global in Performance, 145-64. Newcastle upon Tyne: Cambridge Scholars Publishing.

\section{TDReadings}

Aghaie, Kamran Scot. 2005. "The Origins of the Sunnite-Shi'ite Divide and the Emergence of the Ta'ziyeh Tradition." TDR 49, 4 (T188):42-47. doi.org/10.1162/105420405774763032.

Chelkowski, Peter J. 2005. “Time Out of Memory: Ta'ziyeh, the Total Drama.” TDR 49, 4 (T188):15-27. doi.org/10.1162/105420405774763050.

Chelkowski, Peter J., and Mohammad B. Ghaffari. 2005. "Mohammad B. Ghaffari: Ta'ziyeh Director." TDR 49, 4 (T188):113-29. doi.org/10.1162/105420405774762934.

To view supplemental materials related to this article, please visit https://doi.org/10.1017/S1054204321000745. 